Published in final edited form as:

Biochemistry. 2020 March 24; 59(11): 1149-1162. doi:10.1021/acs.biochem.0c00081.

\title{
Protein Farnesyltransferase Catalyzes Unanticipated Farnesylation and Geranylgeranylation of Shortened Target Sequences
}

\author{
Sudhat Ashok", \\ Department of Chemistry, Syracuse University, Syracuse, New York 13244, United States \\ Emily R. Hildebrandt", Colby S. Ruiz, \\ Department of Biochemistry \& Molecular Biology, University of Georgia, Athens, Georgia 30602, \\ United States \\ Daniel S. Hardgrove, \\ Department of Biochemistry \& Molecular Biology, University of Georgia, Athens, Georgia 30602, \\ United States \\ David W. Coreno, \\ Department of Chemistry, Syracuse University, Syracuse, New York 13244, United States \\ Walter K. Schmidt, \\ Department of Biochemistry \& Molecular Biology, University of Georgia, Athens, Georgia 30602, \\ United States
}

\section{James L. Hougland}

Department of Chemistry and Syracuse Biomaterials Institute, Syracuse University, Syracuse, New York 13244, United States;

\section{Abstract \\ Protein prenylation is a posttranslational modification involving the attachment of a $\mathrm{C} 15$ or $\mathrm{C} 20$ isoprenoid group to a cysteine residue near the $\mathrm{C}$-terminus of the target substrate by protein farnesyltransferase (FTase) or protein geranylgeranyltransferase type I (GGTase-I), respectively. Both of these protein prenyltransferases recognize a C-terminal "CaaX" sequence in their protein substrates, but recent studies in yeast- and mammalian-based systems have demonstrated FTase}

\footnotetext{
Corresponding Author: Phone: (315) 443-1134; hougland@ syr.edu; Fax: (315) 443-4070.

"S.A. and E.R.H. contributed equally to this work.

Supporting Information

The Supporting Information is available free of charge at https://pubs.acs.org/doi/10.1021/acs.biochem.0c00081.

Yeast plasmids and strains used in this study, impact of overexpressing prenylation pathway enzymes on CVI-dependent mating efficiency, peptide/protein information for Cxx sequences tested in the human genome, integrations of FPP/GGPP competition experiments, potential FTase substrate sequences within the human proteome, phenotypes of a-factor CaaX mutants, gel-shift patterns of integrated Ydj1p Cxx variants, steady-state characterization of dns-GCxx peptide prenylation with FPP, steady-state characterization of dns-GCxx peptide prenylation with GGPP, and FPP and GGPP titrations with dns-GCFT (PDF)

Accession Codes

FNTA (protein farnesyltransferase $a$ subunit, Rattus norvegicus), Q04631; FNTB (protein farnesyltransferase $\beta$ subunit, $R$. norvegicus), Q02293; PGTB1_RAT (geranylgeranyl transferase type 1 subunit $\beta, R$. norvegicus), P53610.

The authors declare no competing financial interest.
} 
can also accept sequences that diverge in length from the canonical four-amino acid motif, such as the recently reported five-amino acid $\mathrm{C}(\mathrm{x})_{3} \mathrm{X}$ motif. In this work, we further expand the substrate scope of FTase by demonstrating sequence-dependent farnesylation of shorter three-amino acid "Cxx" C-terminal sequences using both genetic and biochemical assays. Strikingly, biochemical assays utilizing purified mammalian FTase and Cxx substrates reveal prenyl donor promiscuity leading to both farnesylation and geranylgeranylation of these sequences. These findings expand the substrate pool of sequences that can be potentially prenylated, further refine our understanding of substrate recognition by FTase and GGTase-I, and suggest the possibility of a new class of prenylated proteins within proteomes.

\section{Graphical Abstract}

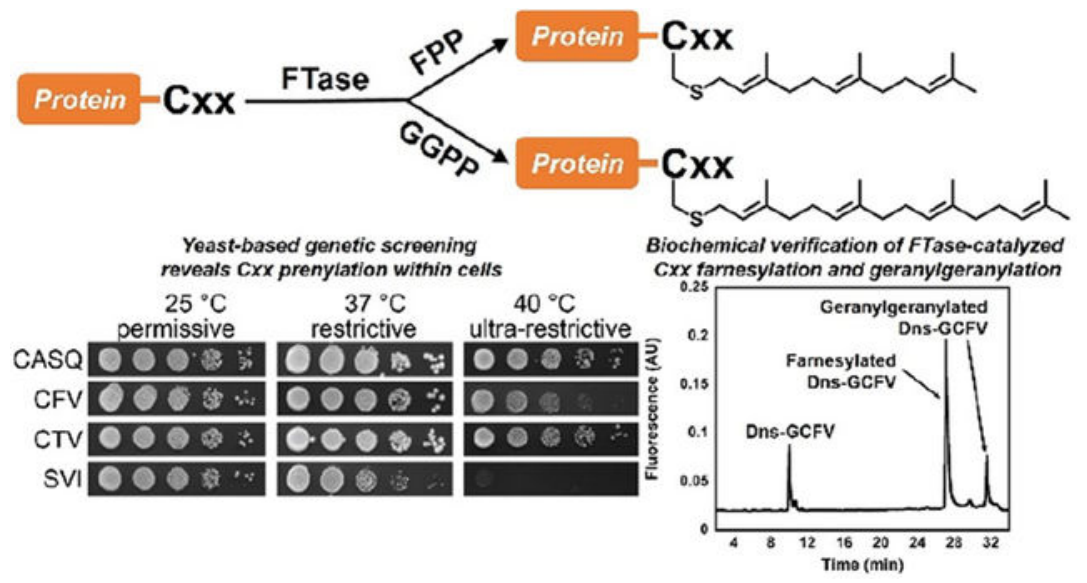

Posttranslational modifications (PTMs) are essential for the proper biological function of many proteins. ${ }^{1}$ Prenylation is one such modification wherein proteins are modified by the covalent attachment of an isoprenoid group to a cysteine residue near the $\mathrm{C}$-terminus of the substrate protein. FTase catalyzes cysteine alkylation with a 15-carbon (C15) farnesyl group from farnesyl diphosphate (FPP) (Scheme 1), whereas GGTase-I performs the reaction with a 20-carbon (C20) geranylgeranyl group. ${ }^{2-6}$ Prenylation augments the hydrophobicity of modified proteins, which can influence membrane association and/or protein-protein interactions that are essential to the biological function of many prenylated proteins. ${ }^{7-12}$

Following prenylation of the cysteine residue, many prenylated proteins undergo two additional processing steps. ${ }^{13,14}$ Proteolytic removal of the amino acids C-terminal to the prenylcysteine is performed by the Rce1p or Ste24p proteases, and the C-terminal prenylcysteine is subsequently methylated by isoprenylcysteine carboxyl methyltransferase (ICMT). These additional postprenylation modifications are vital for the proper function of many prenylated proteins. ${ }^{14-17}$ These additional modifications are not, however, necessarily coupled to prenylation as has been commonly accepted. For example, farnesylation of yeast Ydj1p HSP40 occurs without proteolysis or methylation. ${ }^{18,19}$ While farnesylation is required for optimal Ydj1p activity, proteolysis and carboxymethylation are detrimental to activity. The pathway leading to protein prenylation is emerging to have more complexity than originally anticipated. 
The four-amino acid "CaaX" motif has served as the defining paradigm for substrate selectivity for FTase and GGTase-I for three decades, beginning with the discoveries of prenylation in the context of yeast mating factors, Ras GTPases, and nuclear lamins. ${ }^{20-30}$ This sequence is composed of an invariant cysteine residue that is alkylated on its side-chain thiol, two amino acids commonly reported to be aliphatic, and an X residue that can vary and helps determine peptide reactivity with FTase versus GGTase-I. ${ }^{25,26,31}$ The growing range of known prenylated proteins inspired biochemical, cell-based, and structural examinations of substrate determinants for selectivity by FTase and/or GGTase-I, which have defined rules governing selectivity at each amino acid position within the CaaX motif. 4,26,29,32-37 Structural studies provided an additional framework for understanding FTase and GGTase-I substrate selectivity by revealing specific molecular interactions involved in recognizing both the CaaX substrate sequence and the FPP and GGPP prenyl donor cosubstrates. $^{25,26,38,39}$ Studies guided by FTase and GGTase-I structural models have allowed for efficient reengineering of both peptide and prenyl donor selectivity, further supporting the importance of the interactions observed in these models for enzyme-substrate recognition. ${ }^{36,40,41}$ More recently, bioinformatics and computational/docking approaches have helped predict CaaX motifs as likely FTase and/or GGTase-I substrates. ${ }^{27,28,30}$

Expanding upon the well-established ability of protein prenyltransferases to recognize and modify $\mathrm{CaaX}$ sequences, our recent work supports the novel ability of FTase to modify cysteine residues in other sequence contexts. Both yeast and mammalian FTase can accept longer five-amino acid " $\mathrm{C}(\mathrm{x})_{3} \mathrm{X}$ " sequences as substrates. ${ }^{6}$ We now report that both yeast and mammalian FTase can prenylate shorter three-amino acid Cxx sequences. We demonstrate that yeast FTase can modify Cxx sequences in vivo in the context of Ydj1p Hsp40 while mammalian FTase can modify Cxx reporter peptides in vitro. Unexpectedly, we found that mammalian FTase can accept both FPP and GGPP as the prenyl donor cosubstrate for modification of certain Cxx substrate sequences in the first reported example of wild type FTase catalyzing peptide geranylgeranylation with an efficiency comparable to that of farnesylation. ${ }^{42}$ This new class of FTase substrates and the potential for their promiscuous modification with farnesyl and geranylgeranyl groups increase the complexity of protein prenylation, expanding the potential range of prenylation within proteomes and the roles played by these prenylated proteins in biological systems.

\section{MATERIALS AND METHODS}

\section{Miscellaneous Methods.}

All in vitro FTase and GGTase-I assays were performed at $33{ }^{\circ} \mathrm{C}$. All curve fitting was performed with KaleidaGraph (Synergy Software, Reading, PA). Geranylgeranyl diphosphate (GGPP) and farnesyl diphosphate (FPP) were purchased from Isoprenoids.com (Tampa, FL). Peptides were commercially synthesized (Sigma-Genosys, The Woodlands, TX) and exhibited $>90 \%$ purity, as determined by RP-HPLC or after semiprep purification via RP-HPLC. Peptides were solubilized in ethanol containing 10\% (v/v) DMSO and stored at $-80{ }^{\circ} \mathrm{C}$. Peptide concentrations were determined spectrophotometrically using Ellman's reagent. 
Yeast Strains.

Several of the yeast strains used in this study have been previously described: IH1793 (MATa lys1), RC757 (MATa sst2-1 rme his6 met1 can1 cyh2), SM2331 (MATa trp1 leu2

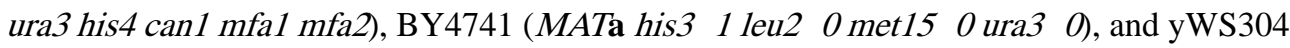

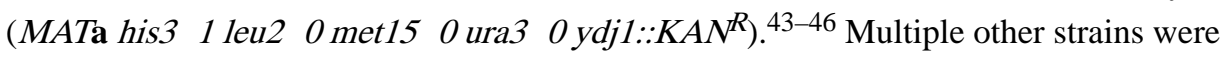

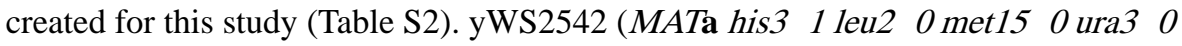
$\operatorname{ram1} 1: K A N^{R}$ ydj1::NAT ${ }^{R}$ ) was created by replacing the $Y D J 1$ open reading frame with the

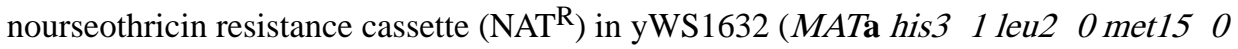
ura3 $\triangle O \operatorname{ram} 1:: K A N^{R}$ ). This was accomplished by transformation of the strain with a restriction enzyme digestion of pWS1623 (BamHI, HindIII, PvuII) and selection on yeast rich medium agar plates (YPD) containing $100 \mu \mathrm{g} / \mathrm{mL}$ nourseothricin. yWS2544 (MATa his $3 \Delta 1$ leu2 $\Delta O$ met $15 \Delta O$ ura3 $\Delta O$ ydj1::NAT ${ }^{R}$ ) was made in a similar fashion using BY4741 as the parent strain. yWS2938-2951 and yWS2958-2959 were created by integrating Ydj1p-Cxx mutants into the $y d j 1:: N A T^{R}$ locus of yWS2544. Integrating DNA fragments were derived by restriction digestion from appropriate $C E N U R A 3$ YDJ1-CXX plasmids (BamHI, Xhol, PvuI, and BgI). Candidate colonies were scored for improved thermotolerance and concomitant loss of nourseothricin resistance. The gene replacements and integrations were confirmed by PCR using primers external and internal to the integrated fragment and sequencing of PCR products derived from the Cxx encoding genomic DNA. Yeast strains were propagated at $30^{\circ} \mathrm{C}$ (IH1793, RC757, SM2331, yWS2938-2952, and yWS2958-2959) or room temperature (yWS2542 and yWS2544) on either YPD or appropriate selective media when plasmid transformed.

\section{Yeast Plasmids and Oligo Designs.}

The plasmids used in this study were either preexisting or newly constructed for this study as noted in Table S1. Unless noted otherwise, new constructs were created in vivo by recombination of a linearized parent plasmid and appropriate PCR-amplified DNA fragments. Plasmids encoding a-factor mutants (i.e., CVI, CV, C, AVI, and SVI) were created using parent plasmid pWS610 (MluI) or pWS817 (PstI and MluI). Plasmids encoding Ydj1p mutants (i.e., CTI, CII, CFV, CVI, AVI, and SVI) were created using parent plasmid pWS1132 (NheI, or NheI and AfII). ${ }^{6,47}$ pWS1623 (CEN URA3 ydj1::NAT ${ }^{R}$ ) was created using a NAT ${ }^{\mathrm{R}}$ PCR product and pWS1132 (NheI and BsaBI). The NAT ${ }^{\mathrm{R}}$ PCR product was derived from $\mathrm{p} 4339$ and was designed to have a flanking sequence identical to the $5^{\prime}$ and $3^{\prime}$ UTRs of the YDJ1 ORF. pWS114 ( $2 \mu$ URA3 RCE1) was constructed by subcloning the $B g I$ fragment from pSM1275 (CEN URA3 RCEI) into the BgI site of pSM217. ${ }^{45,48}$ pWS1808 ( $2 \mu$ URA3 RAMI) was constructed in two steps. First, pWS1767 (CEN URA3 RAMI) was created through in vivo recombination of HindIII-linearized pRS316 ( $C E N U R A 3$ ) and a PCR-derived DNA fragment containing the RAM1 gene that was amplified from BY4741 genomic DNA. Second, the Xhol-Sacl fragment from pWS1767 was subcloned into the same sites of pRS426 ( $2 \mu$ URA3).$^{49}$ Introduction of plasmids, plasmid digests, and PCR-derived DNA fragments into yeast strains occurred via a lithium acetate-based transformation procedure. ${ }^{50}$

The synthetic oligonucleotides used for generating random $\mathrm{Cxx}$ sequences that underwent genetic screening were based on the CaaX encoding region of either MFA1 or YDJ1 as 
encoded in pWS1024 or pWS1132, respectively. The forward PCR oligo encoded the Cxx sequence and was flanked by sequences on the $5^{\prime}$ and $3^{\prime}$ ends that were homologous to the target gene; the $5^{\prime}$ sequence facilitates recombination, and the $3^{\prime}$ sequence facilitates PCR priming. All nucleotides were allowed at the $\mathrm{x}$ positions, allowing for the formation of all $400 \mathrm{Cxx}$ permutations and also two nonsense mutations (i.e., C-stop and Cx-stop). The reverse oligo matched a region in the polylinker sequence adjacent to the $3^{\prime}$ UTR of each gene. The synthetic oligonucleotides used for generating specific $\mathrm{Cxx}$ sequences were as described above for random Cxx sequence but were individually designed to create the desired Cxx sequence. The synthetic oligonucleotides used to amplify the RAM1 gene contained $5^{\prime}$ sequences homologous to the recipient vector pRS316 to facilitate recombination and $3^{\prime}$ sequences homologous to intergenic regions surrounding the RAM1 gene to facilitate PCR priming such that 491 and 271 nucleotides of the $5^{\prime}$ and $3^{\prime}$ intergenic regions were amplified, respectively.

\section{a-Factor Mating Pheromone Screen, Halo Assay, and Mating Test.}

MATa yeast lacking the MFA1 and MFA2 a-factor genes (SM2331) were co-transformed with digested pWS1024 (MluI and SphI) and a PCR product encoding randomized Cxx sequences. The transformation mix was plated on synthetic complete agar plates lacking leucine (SC-leucine) and incubated at $30{ }^{\circ} \mathrm{C}$ for $72-96 \mathrm{~h}$ to allow colonies to form. Colony counts were determined before replica plating the colonies onto an SC-leucine plate (replica plate) and a minimal medium plate (diploid-selective) containing a thin lawn of IH1793 yeast. Plates were incubated at $30{ }^{\circ} \mathrm{C}$ for $72-96 \mathrm{~h}$; diploid colonies were identified, and the corresponding MATa parent colony was recovered from the SC-leucine replicate plate. The MATa strains were individually cultured to saturation and spotted onto a lawn of MATa sst2-1 yeast (RC757), and strains visually scored for the strength of halo production. Plasmids were isolated and sequenced from the strongest halo-producing strains. For figure production, plasmid transformants of SM2331 were cultured to saturation in selective SCleucine liquid media, cultures pinned onto SC-leucine plates, plates incubated for $24-36 \mathrm{~h}$ at $30{ }^{\circ} \mathrm{C}$, and the dense spots of growth replica transferred onto a thin lawn of RC757 yeast. Plates were scanned as described below after incubation at $30^{\circ} \mathrm{C}$ for $16-20 \mathrm{~h}$.

Quantitative mating was performed as previously described. ${ }^{6,18}$ MATa strains derived from SM2331 to express the indicated a-factor Cxx mutants were cultured to saturation in selective liquid media, diluted to an $A_{600}$ of $\sim 1.0$ using fresh culture media, and then mixed with an excess of the IH1793 MATa lys 1 strain cultured and diluted in the same manner but with nonselective YPD. The number of colony-forming units (CFUs) was determined on both SC-lysine and synthetic minimal medium agar plates (SD) using empirically determined dilutions; SC-lysine selects for the total of MATa haploid and MATa/a diploid cells, while SD selects for diploids only. Mating frequencies (CFUdiploid/CFUtotal) were determined for each mutant and are reported as a percentage relative to a strain producing wild type a-factor.

\section{Thermotolerance Screen and Assays.}

The Ydj1p screen was performed essentially as previously described. ${ }^{6}$ In brief, yeast lacking the YDJ1 gene (yWS304) were co-transformed with the PCR product encoding randomized 
Cxx sequences and digested pWS1132 (Nhel). A portion of the transformation mix was plated on SC-uracil solid medium and incubated at $25^{\circ} \mathrm{C}$ for $96 \mathrm{~h}$ to assess the total number of CFUs in the mix. The remaining transformation mix was plated on YPD solid medium and incubated at $40{ }^{\circ} \mathrm{C}$ for $96 \mathrm{~h}$. Plasmids were recovered from thermotolerant colonies, sequenced, and reintroduced into yWS304 to confirm plasmid-linked thermotolerance prior to detailed thermotolerance analysis involving incubation at various temperatures $(25,37$, or $40{ }^{\circ} \mathrm{C}$ ). In brief, saturated cultures grown at room temperature in SC-uracil liquid medium were serially diluted into YPD, dilutions pinned onto YPD solid medium, and plates incubated for several days at the desired temperature. Each experiment was performed at least twice on separate days, and each strain was evaluated in duplicate within each experiment.

\section{Estimate of Cxx Complexity in a-Factor and Thermotolerance Screens.}

The GLUE-IT algorithm was used to estimate coverage of the screen. ${ }^{51}$ The algorithm takes into account the CFUs evaluated for each screen and the number and redundancy of the codons used for amino acid randomization. The number of colonies associated with transformation of linearized plasmids or PCR products alone (i.e., false positives) was not counted toward the CFU total. The false positive rate was typically low $(<2 \%)$ relative to that of the co-transformed sample. In the case of the thermotolerance screen, the $\mathrm{CFU}$ value derived from growth observed on $\mathrm{SC}$-uracil solid medium at $25^{\circ} \mathrm{C}$ (i.e., $~ 8400$ ) was adjusted to $14 \%$ of its value to account for the observation that incubation at $40{ }^{\circ} \mathrm{C}$ reduces the transformation efficiency. ${ }^{19}$

\section{Immunoblot Analysis for Protein Prenylation in Yeast.}

Whole cell lysates of mid log yeast were prepared as previously described, separated by sodium dodecyl sulfate-polyacrylamide gel electrophoresis (SDS-PAGE) (14\%), and transferred onto nitrocellulose, and blots were incubated with the rabbit anti-Ydj1p primary antibody (courtesy of A. Caplan) and HRP-conjugated goat anti-rabbit secondary antibody (Kindle Biosciences, Greenwich, CT) ${ }^{18,52}$ Immune complexes were detected using a KwikQuant Imager at multiple exposure times after development of blots with the KwikQuant Western Blot Detection Kit (Kindle Biosciences).

\section{Image Analysis for Yeast Plates and Immunoblot Films.}

A flat-bed scanner was used to image plates at $300 \mathrm{dpi}$ (grayscale). Plates were scanned face down without lids using a black background. Digitized TIFF images of plates and immunoblots were imported into Photoshop for minor adjustments (i.e., image rotation, contrast, cropping, etc.) and then copied to PowerPoint for final figure assembly. Contrast settings within Photoshop were adjusted for all plate images to be identical and to maximize the dynamic range of the signal; settings for immunoblot images were unchanged.

\section{Expression and Purification of FTase and GGTase-I.}

Rat FTase and GGTase-I were expressed in BL21(DE3) Escherichia coli and purified as previously described. ${ }^{6,40}$ 


\section{RP-HPLC-Based Assay for Screening the Reactivity of dns-GCxx Peptides and Assessing Prenylation Prefer ence by FTase.}

Dns-peptides $(3 \mu \mathrm{M})$ were diluted into $1 \times$ FTase reaction buffer $[50 \mathrm{mM}$ HEPPSO-NaOH (pH 7.8), $5 \mathrm{mM}$ TCEP, and $5 \mathrm{mM} \mathrm{MgCl} 2 ; 50 \mu \mathrm{L}$ total] and incubated for $20 \mathrm{~min}$ in $0.65 \mathrm{~mL}$ of low-adhesion microcentrifuge tubes. Prenylation reactions were initiated by adding an enzyme mix ( $200 \mathrm{nM}$ rat FTase, $10 \mu \mathrm{M}$ FPP or GGPP, in $1 \times$ FTase reaction buffer). Reaction mixtures were incubated at $33{ }^{\circ} \mathrm{C}$ for $16 \mathrm{~h}$, and then reactions quenched with an equal volume of $20 \%$ acetic acid in isopropanol. RP-HPLC analysis was performed at ambient temperature on an Agilent 1260 HPLC system with autosampler, UV-vis, and fluorescence detection using a C18 reversed-phase analytical column (Zorbax XDB-C18) with a linear gradient from $30 \%$ acetonitrile in $25 \mathrm{mM}$ ammonium acetate to $100 \%$ acetonitrile flowing at a rate of $1 \mathrm{~mL} / \mathrm{min}$ over $30 \mathrm{~min}$; peptides and products were detected by fluorescence $\left(\lambda_{\mathrm{ex}}=\right.$ $\left.340 \mathrm{~nm} ; \lambda_{\mathrm{em}}=496 \mathrm{~nm}\right)$. Chromatogram analysis and peak integration were performed using Chemstation for LC (Agilent Technologies).

For prenyl donor preference assays, the reactivity of dns-GCxx peptides (CFT, CFV, CGF, $\mathrm{CMF}$, and CVF) was evaluated as described above with varying concentrations of FPP and GGPP (10 $\mu \mathrm{M}$ FPP only, $7.5 \mu \mathrm{M}$ FPP with $2.5 \mu \mathrm{M}$ GGPP, $5 \mu \mathrm{M}$ FPP with $5 \mu \mathrm{M}$ GGPP, 2.5 $\mu \mathrm{M}$ FPP with $7.5 \mu \mathrm{M}$ GGPP, and $10 \mu \mathrm{M}$ GGPP only).

\section{Fluorescence-Based Assay for Screening the Reactivity of dns-GCxx Peptides, Determining Prenyl Donor Saturating Concentrations, and Determining Steady-State Kinetic Parameters.}

Steady-state kinetic parameters were determined for FTase from a time-dependent increase in fluorescence $\left(\lambda_{\mathrm{ex}}=340 \mathrm{~nm} ; \lambda_{\mathrm{em}}=520 \mathrm{~nm}\right)$ upon prenylation of the dansylated peptide, with assays performed with $0.5-10 \mu \mathrm{M}$ dansylated peptide, $100 \mathrm{nM}$ purified rat FTase, and $10 \mu \mathrm{M}$ FPP or GGPP in $1 \times$ FTase reaction buffer at $33{ }^{\circ} \mathrm{C}$ in a 96 -well plate (Corning); reactivity screening was performed using $3 \mu \mathrm{M}$ peptide. Peptides were incubated in reaction buffer for 20 min prior to initiation of the reaction by addition of FTase and prenyl donor. The fluorescence was monitored over a period of $7-8 \mathrm{~h}$ at $33{ }^{\circ} \mathrm{C}$ in the BioTek H1 Synergy plate reader $\left(\lambda_{\mathrm{ex}}=340 \mathrm{~nm} ; \lambda_{\mathrm{em}}=520 \mathrm{~nm}\right)$ with fluorescence measured at intervals of 30 $40 \mathrm{~s}$. The initial velocity for prenylation of dns-GCxx peptides was determined from a timedependent increase in fluorescence upon prenylation of the dansylated peptide. To confirm that $10 \mu \mathrm{M}$ FPP and GGPP represented a saturating concentration of these co-substrates (Figure S5), assays were performed as described above with $3 \mu \mathrm{M}$ dns-GCFT peptide, 100 $\mathrm{nM}$ purified rat FTase, and 2-10 $\mu \mathrm{M}$ FPP or GGPP in $1 \times$ FTase reaction buffer at $33{ }^{\circ} \mathrm{C}$ in a 96-well plate (Corning). The initial velocities for dns-GCFT prenylation using both FPP and GGPP prenyl donors decrease $<2$-fold when the prenyl donor concentration is decreased from 10 to $2 \mu \mathrm{M}$, consistent with $10 \mu \mathrm{M}$ representing saturating prenyl donor (Figure S5).

To obtain steady-state $\left(k_{\mathrm{cat}} t K_{\mathrm{m}}\right)$ parameters for peptide reactivity, the total fluorescence change observed upon completion of the reaction was divided by the initial concentration of the peptide substrate in a given reaction to yield a conversion factor from fluorescence units to product concentration (micromolar). These values were averaged over several peptide concentrations to give an amplitude conversion (AmpConv), whose units are fluorescence 
units per micromolar of product formed $(\mathrm{Fl} / \mu \mathrm{M})$. The linear initial rate, whose units are fluorescence intensity per second ( $\mathrm{Fl} / \mathrm{s})$, was converted to a velocity $(\mu \mathrm{M} / \mathrm{s})$ using eq 1 , where $V$ is the velocity $(\mu \mathrm{M} / \mathrm{s}), R$ is the velocity $(\mathrm{Fl} / \mathrm{s})$, and AmpConv is the ratio described above $(\mathrm{Fl} / \mu \mathrm{M})$.

$$
V=R / A m p C o n v
$$

The reaction velocities ( $V$ ) were divided by the enzyme concentration $(\mu \mathrm{M})$ to obtain $V /[\mathrm{E}]$ ratios having units of inverse seconds. A steady-state kinetic parameter $\left(k_{\text {cat }} / K_{\mathrm{m}}\right)$ was determined from a fit of the Michaelis-Menten equation to the dependence of the initial velocity divided by the enzyme concentration $(V /[\mathrm{E}])$ on the peptide concentration in the presence of saturating prenyl donor $(10 \mu \mathrm{M})$. Errors represent the standard deviation from three replicate measurements.

\section{RP-HPLC-Based and Fluorescence-Based Assays for Screening the Reactivity of dns- GCxx Peptides by GGTase-I.}

Dns-peptides $(3 \mu \mathrm{M})$ were diluted into $1 \times$ GGTase-I reaction buffer [50 mM HEPPSO$\mathrm{NaOH}$ (pH 7.8) and $5 \mathrm{mM}$ TCEP; $50 \mu \mathrm{L}$ total] and incubated for $20 \mathrm{~min}$ in $0.65 \mathrm{~mL}$ lowadhesion microcentrifuge tubes. Prenylation reactions were initiated by adding an enzyme mix (200 nM rat GGTase-I, $10 \mu \mathrm{M}$ GGPP, in $1 \times$ reaction buffer). Reaction mixtures were incubated at $33{ }^{\circ} \mathrm{C}$ for $16 \mathrm{~h}$, and then reactions quenched with an equal volume of $20 \%$ acetic acid in isopropanol. RP-HPLC analysis was performed in a manner similar to that of reactions with FTase. The fluorescence-based assay was monitored over a period of $10 \mathrm{~h}$ at $33{ }^{\circ} \mathrm{C}$ in the BioTek H1 Synergy plate reader $\left(\lambda_{\mathrm{ex}}=340 \mathrm{~nm} ; \lambda_{\mathrm{em}}=520 \mathrm{~nm}\right)$ with fluorescence measured at intervals of $37 \mathrm{~s}$.

\section{LC-MS Analysis of dns-GCxx Peptides Modified by FTase.}

In vitro reaction mixtures with dns-GCxx peptides $(3 \mu \mathrm{M})$ were prepared in $1 \times$ FTase reaction buffer in the presence of rat FTase $(200 \mathrm{nM})$ and prenyl donor $(10 \mu \mathrm{M})$ and incubated at $33{ }^{\circ} \mathrm{C}$ for $16 \mathrm{~h}$ before isolation of the farnesylated or geranylgeranylated peptide by RP-HPLC. Reaction mixtures $(2 \mathrm{~mL}$ ) were purified via semipreparative RP-HPLC (Zorbax Eclipse XDB-C18 column, $9 \mathrm{~mm} \times 250 \mathrm{~mm}$ ) using a linear gradient of 30:70 TFA in water $(0.05 \%)$ /acetonitrile (HPLC grade) with a flow rate of $3.2 \mathrm{~mL} / \mathrm{min}$ over $42 \mathrm{~min}$. The peak corresponding to the prenylated peptide was detected by UV absorbance at $360 \mathrm{nM}$, with this peak collected and dried under reduced pressure overnight before the sample was redissolved in $50 \%$ acetonitrile. The product peptide mass was determined by LC-MS (ESI) using a Shimadzu LCMS-8040 mass spectrometer with a mobile phase of 5\% ACN and 95\% water used at a flow rate of $0.2 \mathrm{~mL} / \mathrm{min}$ using $5 \mu \mathrm{L}$ of the purified prenylated peptide dissolved in 50\% ACN and deionized water; the peak intensity was monitored from $\mathrm{m} / z 200$ to 2000 . 


\section{RESULTS}

\section{Genetic Screening in Yeast Reveals Prenylation of Cxx Sequences Can Occur in Vivo.}

We recently reported that pentapeptide $\mathrm{C}(\mathrm{x})_{3} \mathrm{X}$ sequences can support prenylation of yeast genetic reporters based on the a-factor mating pheromone and Ydj1p Hsp40 chaperone. ${ }^{6}$ Using these same reporters and complementary selection screens, we have established that certain tripeptide Cxx sequences are also recognized and modified by yeast FTase in vivo.

The biological activity of the yeast $\mathbf{a}$-factor mating pheromone normally depends on farnesylation, proteolysis, and carboxylmethylation of the CVIA CaaX motif associated with its precursor. To explore whether shorter sequences could be similarly modified, we evaluated a set of a-factor mutants ending in CVI, CV, and C. Using MATa mfa1 mfa2 yeast that cannot make a-factor on their own, we introduced the plasmid-encoded a-factor mutants and performed the a-factor halo assay. In this assay, MATa cells are either spotted or replica printed onto a thin lawn of MATa sst2-1 yeast that are supersensitive to a-factor mating pheromone. The release of a-factor by MATa cells results in a zone of MATa cell growth inhibition (i.e., halo) surrounding the MATa cells. We observed a strong halo in association with the plasmid encoding wild type a-factor (Figure S1, CVIA), a moderate halo with $\mathrm{CVI}$, and no halos with -C, -CV, or the vector control. The observed activity for a-factor$\mathrm{CVI}$ was dependent on the presence of cysteine within the $\mathrm{C}$-terminal sequence because halos were not observed with a-factor-AVI or -SVI. We reasoned that the most likely explanation for the observed -CVI halo was weak prenylation and/or proteolysis of the afactor CVI sequence.

To more fully explore the potential for other Cxx sequences to support a-factor production, we pursued a genetic selection scheme using a plasmid library of a-factor-Cxx variants. We transformed the plasmid library into MATa mfa1 mfa2 yeast and identified mating competent colonies by replica printing the MATa colonies onto a thin lawn of MATa yeast and selecting on diploid-selective yeast medium. We pursued a yeast mating approach (i.e., positive selection) over the halo assay approach (i.e., screening) for easier identification of a-factor-producing colonies. Of $\sim 8100$ colonies screened, 45 diploid colonies were identified. The corresponding haploid parents were recovered from the replica master and scored for their a-factor production phenotype using the halo assay. A subset of 19 colonies having the strongest halo production was identified, and associated plasmids were recovered and sequenced (Table S1). A reduced set of 10 plasmids represented the unique Cxx sequences after the elimination of duplicate sequences (i.e., CII, CTI, and CVI). We estimate that $\sim 99 \%$ of $\mathrm{Cxx}$ sequence space was evaluated during the selection strategy (see Materials and Methods for a description of the coverage estimate). The plasmids were re-transformed into MATa $\mathrm{mfa} 1 \mathrm{mfa} 2$ yeast and retested for the ability to confer a-factor production using the halo assay (Figure 1a). The halos formed with Cxx sequences were similar in size to each other, and all were smaller than that associated with wild type a-factor (CVIA), implying overall less a-factor production was associated with this wide variety of $\mathrm{Cxx}$ sequences. The a-factor halo assay is an extremely sensitive and qualitative method for measuring a-factor production that quickly saturates at low levels of pheromone. ${ }^{18} \mathrm{~A}$ quantitative mating assay for better assessment of $\mathbf{a}$-factor production revealed that $\mathrm{Cxx}$ 
sequences were far less effective at promoting mating than wild type a-factor (Figure 1b); similar results were previously observed with longer $\mathrm{C}(\mathrm{x})_{3} \mathrm{X}$ sequences. ${ }^{6}$ Still, mating for Cxx sequences was reproducible, and the level was higher than that observed for unprenylated a-factor variants (i.e., a-factor-C, -CV, -AVI, and -SVI), for which no mating was ever observed. We also investigated whether an increased level of expression of genes associated with a-factor production could improve mating of a-factor-CVI (Figure 1c and Table S3). Whereas overexpressed RAM1 (FTase $\beta$ subunit) and STE24 (protease) had levels of mating comparable to that of the vector control, overexpressed RCE1 (CaaX protease) increased the rate of mating, suggesting that proteolysis of CVI by Rce1p may be limiting for production of $\mathbf{a}$-factor in this instance.

By comparison to the a-factor reporter, Hsp40 Ydj1p requires only farnesylation of its CASQ CaaX motif to support its role in yeast thermotolerance. It does not undergo CaaX proteolysis and carboxymethylation, which are actually detrimental to its activity. 6,18,19,53 We thus adapted Ydj1p as a more direct reporter for farnesylation of Cxx sequences. We transformed a plasmid library of Ydj1p Cxx mutants into ydj1 $1 \Delta$ yeast and identified thermotolerant colonies. ${ }^{6}$ Of $\sim 1200$ colonies screened, 13 thermotolerant colonies were identified. The associated plasmids were recovered and sequenced (Table S1). A reduced set of 10 plasmids represented the unique sequences after eliminating duplicate sequences (CAL, CEV, and CLL). We estimate that $\sim 82 \%$ of Cxx sequences were evaluated during the screen (see Materials and Methods for a description of the coverage estimate). The ability of these Cxx sequences to support prenylation was confirmed using a thermotolerance assay (Figure 2a). Several of the Cxx sequences identified using the a-factor reporter were transferred onto Ydj1p and also evaluated (i.e., CTI, CII, CFV, and CVI). The growth observed for all mutants was qualitatively better than that observed for nonprenylated Ydj1p mutants that fail to grow at $40{ }^{\circ} \mathrm{C}$ (i.e., AVI and SVI). Most mutants exhibited a thermotolerance phenotype similar to that observed for wild type Ydj1p (CASQ) that is prenylated but uncleaved, and a few displayed an intermediate phenotype similar to that observed for a prenylated and cleaved Ydj1p mutant (CTLM). Prenylation of Ydj1p also affects its mobility in SDS-PAGE such that the farnesylated protein has increased mobility (i.e., smaller apparent molecular weight) relative to unprenylated; the latter can be produced by expression in a FTase-deficient yeast strain (i.e., ram1). All of the Ydj1p Cxx hits exhibited prenylation, albeit partially in most cases (Figure 2b). Importantly, Ydj1p-AVI and -SVI variants neither were thermotolerant nor displayed a gel shift, implying lack of prenylation and consistent with results derived using a-factor-AVI and -SVI. To confirm that observed gel shift phenotypes were not due to plasmid-based overexpression of the Ydj1p reporter, each Cxx hit was subsequently integrated into the genome as the sole copy of Ydj1p and the gel shift reassessed; thermotolerance was also assessed. More complete prenylation of Ydj1p-Cxx variants was quantifiably observed, with several displaying complete modification (Figure $2 \mathrm{~b}$ and Figure S2). The Cxx sequences recovered with the afactor reporter (i.e., CTI, CII, CFV, and CVI) were generally prenylated to a greater extent than those directly recovered with the Ydj1p reporter as assessed by gel shift, while two displayed weaker thermotolerance (i.e., CFV and CVI). We consider these observations to be consistent with the hypothesis that a-factor-derived sequences are likely more extensively modified after initial prenylation (i.e., cleaved and carboxylmethylated), which is known to 
diminish Ydj1p-based thermotolerance. ${ }^{18,19}$ Because complete or near complete prenylation of Cxx sequences occurs in the context of Ydj1p in vivo, this suggests the possibility that such sequences may be modified when in a natural protein context.

Farnesylation of Cxx Peptide Substrates by Mammalian Prenyltransferases.

While the prenylation activity observed with C-terminal Cxx sequences in yeast suggests these sequences may also serve as substrates for mammalian prenyltransferases, the yeast and mammalian FTase orthologs have been shown to exhibit non-identical but largely overlapping peptide selectivities. ${ }^{55}$ Accordingly, we determined the ability of purified mammalian FTase and GGTase-I to prenylate Cxx sequences in the context of fluorescently labeled synthetic peptides (dns-GCxx). To augment $10 \mathrm{Cxx}$ sequences selected from those identified as prenylation substrates by genetic screening (see Figures 1 and 2), we constructed a peptide panel including Cxx sequences derived from the human proteome. A Prosite database scan revealed 1074 human proteins with C-terminal Cxx sequences, with 847 of these not contained within longer $\mathrm{CaaX}$ or $\mathrm{C}(\mathrm{x})_{3} \mathrm{X}$ sequences or associated with $\mathrm{CC}$ or $\mathrm{CxC}$ sequences that can serve as Rab GGTase-II substrates. ${ }^{56}$ From this pool, 75 candidate $\mathrm{Cxx}$ sequences were selected for detailed analysis on the basis of the following requirements: annotated membrane localization of the parent protein, conservation of the cysteine in at least two other species, evidence of protein expression, and lack of any predicted transmembrane helices (Table S4). This list of human-derived sequences included 12 sequences that were identified by genetic screening in yeast.

The panel of 85 dns-GCxx peptides were screened for prenylation activity with rat FTase and GGTase-I using RP-HPLC to directly detect the prenylated product. ${ }^{6}$ Farnesylation of 64 of the 85 peptide sequences was confirmed, with the extent of peptide farnesylation following overnight incubation ( $\sim 16 \mathrm{~h}$ ) varying across these 64 sequences and 26 peptides reacting to completion (Table 1 and Figure 3 ). The varying reactivity of these Cxx peptides indicates that FTase exhibits sequence selectivity with these truncated prenylation motifs rather than recognizing the cysteine thiol side chain alone. In contrast to FTase, we did not observe peptide geranylgeranylation upon incubation with GGTase-I and GGPP under analogous conditions, demonstrating these shorter peptide sequences do not serve as GGTase-I substrates.

As further validation of dns-GCxx prenylation, farnesylation of two representative dnsGCxx peptides by FTase was confirmed by mass spectrometry (Figure 4). Two major ions were observed for dns-GCYL, corresponding to the farnesylated peptide $(\mathrm{M}+\mathrm{H}=892 \mathrm{Da})$ and a higher-molecular weight peak consistent with oxidation of the farnesyl cysteine thioether to a sulfone ( $\mathrm{S}=\mathrm{O} ; \mathrm{M}+16+\mathrm{H}=908 \mathrm{Da}$ ) as has been noted in mass spectrometry of related molecules ${ }^{57}$ For dns-GCWI, only one major species was identified, corresponding to an oxidized farnesylated product $(\mathrm{S}=\mathrm{O} ; \mathrm{M}+16+\mathrm{H}=931 \mathrm{Da})$.

\section{Geranylgeranylation of Cxx Peptide Sequences by FTase.}

The selectivity of FTase for FPP over GGPP as a prenyl donor has been ascribed to steric clashes between FTase active site residues and the larger GGPP when it occupies the active site, with certain engineered FTase active site mutations relieving this clash. ${ }^{39,41,58}$ With the 
Cxx sequences being one amino acid shorter than the established CaaX prenylation motif, we hypothesized that FTase might be able to accommodate the larger isoprenoid donor GGPP for prenylation. Indeed, geranylgeranylation was observed for 38 of the $85 \mathrm{dns}-\mathrm{Cxx}$ peptides by RP-HPLC when reaction mixtures contained FTase and GGPP (Figure 5 and Table 1). FTase-catalyzed geranylgeranylation of Cxx peptides exhibited sequencedependent variation of peptide reactivity with only five peptides exhibiting complete or near complete modification. Geranylgeranylation of two representative dns-GCxx peptides, dnsGCFT ( $=$ O; M + 16 + H = 948 Da) and dns-GCYL ( $=$ O; $\mathrm{M}+16+\mathrm{H}=976 \mathrm{Da})$, was verified by mass spectrometry (Figure 6 ).

\section{Competition Assay for Assessing the FTase Preference for FPP versus GGPP.}

With FTase able to use either FPP or GGPP to modify Cxx sequences, we determined the relative lipid preference for FTase between these two co-substrates using direct competition. We investigated this issue using five peptides (dns-GCFT, dns-GCFV, dns-GCGF, dnsGCMF, and dns-GCVF) that displayed the highest activity with GGPP in the RP-HPLC assay (Table 1 and Table S5). Each peptide was incubated with FTase and $10 \mu \mathrm{M}$ total prenyl donor, where the molar ratio of the lipid varied from 100\% GGPP to 100\% FPP. Following the reaction, the modification associated with the product (farnesylation or geranylgeranylation) was determined by its RP-HPLC retention time (Figure 7a). For each peptide, the relative amount of geranylgeranylated product decreases in favor of farnesylation even when GGPP represents the majority (i.e., 75\%) of a prenyl donor available (Figure 7b-f). This indicates a strong preference for FPP as an FTase co-substrate under most conditions but allows for unexpected use of GGPP in the absence of a farnesyl donor.

\section{Steady-State Analysis of dns-GCxx Peptide Prenylation by FTase.}

For steady-state analysis of Cxx prenylation by FTase and GGTase-I, we used an established fluorescence-based assay that employs the environmentally sensitive dansyl fluorophore to allow continuous monitoring of peptide prenylation. ${ }^{59,60}$ Upon prenylation, dansylated peptides exhibit fluorescence enhancement that allows for more facile measurement of initial reaction rates compared to HPLC-based assays (Figures S3 and S4). Surprisingly, only 12 of the 85 peptides in our study set exhibited fluorescence enhancement upon reaction with FTase and FPP, consistent with peptide farnesylation. By comparison, 64 peptides were confirmed to be farnesylated by RP-HPLC analysis under identical reaction conditions (Supporting Information). The high false negative rate for detecting peptide farnesylation through the fluorescence-based assay mirrors that observed for longer $\mathrm{C}(\mathrm{x})_{3} \mathrm{X}$ peptide sequences,${ }^{6}$ suggesting restrictions on the utility of the fluorescence-based assay for determining peptide reactivity with FTase. Importantly, we note that no false positives were observed with the fluorescence-based assay for peptides that were deemed to be unreactive by RP-HPLC analysis. In reactions with FTase and GGPP, four of the 85 peptides exhibited fluorescence enhancement (dns-GCFT, dns-GCII, dns-GCLL, and dns-GCYL). None of the 85 dns-GCxx peptides yielded fluorescence enhancement upon reaction with mammalian GGTase-I and GGPP, consistent with the lack of Cxx peptide reactivity with GGTase-I observed by RP-HPLC analysis. 
Steady-state characterization of peptide reactivity was performed for dns-GCxx peptides exhibiting fluorescence enhancement upon prenylation with either FPP or GGPP in the presence of a saturating $(10 \mu \mathrm{M})$ prenyl donor co-substrate (Table 2 and Supporting Information). Saturation of prenylation velocity was not observed within the experimentally accessible peptide concentration range for any of the peptides tested, allowing measurement of only $k_{\mathrm{cat}} / K_{\mathrm{m}}$ for these FTase substrates. In a reaction with FPP, dns-GCxx peptides exhibited much less reactivity as compared to highly reactive CaaX sequences, such as the H-Ras-derived CVLS sequence. ${ }^{61}$ For example, dns-GCLL was farnesylated $\sim 40$-fold less efficiently by FTase than dns-GCVLS under subsaturating $\left(k_{\text {cat }} / K_{\mathrm{m}}\right)$ conditions. For the Cxx peptides for which steady-state reactivity with both FTase and GGPP could be determined, all peptides exhibited comparable reactivity (within 2-fold) in the presence of saturating FPP or GGPP.

\section{DISCUSSION}

Prenylation by FTase and GGTase-I is an important posttranslational modification within eukaryotic proteomes. The canonical CaaX C-terminal motif is generally accepted as the prenylation target of these enzymes. Our recent finding that FTase can target longer $\mathrm{C}(\mathrm{x})_{3} \mathrm{X}$ sequences has expanded the potential substrate scope for this enzyme, ${ }^{6}$ which we have further expanded by our current findings that FTase can accept shorter Cxx sequences. The Cxx sequences that we identified in vivo using yeast-based a-factor and Ydj1 reporter assays were also among the most reactive in our in vitro studies using human FTase, suggesting these identified Cxx sequences have potential biological relevance. In this study, we additionally demonstrate that mammalian FTase can utilize GGPP as the prenyl donor for modification of a subset of Cxx sequences. While FTase can be mutated to allow GGPP to serve as the prenyl donor, ${ }^{41}$ this is the first reported example of wild type FTase catalyzing peptide geranylgeranylation with an efficiency comparable to that of farnesylation of the same sequences. Our findings support the investigation of proteins terminating in $\mathrm{Cxx}$ sequences in cellular systems to determine their prenylation status and the impact of such modification on the biological activities of $\mathrm{Cxx}$ proteins.

This work expands both the peptide and prenyl donor substrate pools for FTase, which further highlights the truly remarkable degree of substrate flexibility exhibited by this enzyme. By contrast, the inability of GGTase-I to accept dns-GCxx sequences as substrates demonstrates that it displays stricter peptide length and sequence determinants than FTase. While the outcome of our FPP/GGPP competition assay clearly shows FTase has a preference for FPP over GGPP as a prenyl donor, the promiscuous utilization of GGPP as a prenyl donor could lead to alternative prenylation when FPP levels are depleted. It is also possible that certain Cxx sequences can be preferentially geranylgeranylated by FTase, as it is well established for $\mathrm{CaaX}$ sequences that there is interplay between peptide sequence and prenyl donor selectivity. ${ }^{61-64}$ Indeed, in this study using a-factor and Ydj1p reporters, while we assume the Cxx sequences are modified with farnesyl, we cannot formally discount the possibility that geranylgeranylation has also occurred. We expect to gain a better understanding of how FTase utilizes FPP and GGPP for prenylation of Cxx sequences through future structural and computational modeling studies of peptides from this new substrate class in complex with FTase and prenyl donors. 
In interpreting the biochemical significance of FTase-catalyzed Cxx sequence prenylation, we believe it is important to consider whether these sequences are being recognized as peptide/protein sequences or merely as thiols with appended functional groups. Previous work has shown FTase can farnesylate nonpeptidic thiols such as dithiothreitol and methyl thioglycolate (MTG) ${ }^{65}$ That study demonstrated that coordination of thiol to the catalytic zinc ion of FTase can lead to substrate binding, but peptide interactions enhance binding and catalysis. Our data suggest that the latter occurs with Cxx sequences. First, the steady-state parameters $\left(k_{\mathrm{cat}} t K_{\mathrm{m}}\right)$ determined for Cxx sequences range from 200- to 2300-fold higher than the highest $k_{\mathrm{cat}} / K_{\mathrm{m}}$ reported for a nonpeptidic thiol (MTG, $1.7 \mathrm{M}^{-1} \mathrm{~s}^{-1}$ ). ${ }^{65}$ Second, the substrate selectivity between Cxx peptides exhibited in FTase reactions with both FPP and GGPP prenyl donors indicates the peptide sequence strongly influences the ability of FTase to accept these peptides as substrates. Together, our findings support the idea that the Cxx substrates are recognized by FTase as peptide sequences, although with a reactivity lower than that of CaaX sequences.

With regard to the future, assessing the impact of $\mathrm{Cxx}$ sequence prenylation in biological systems represents the most important research avenue motivated by our current findings. Within yeast, we have demonstrated the ability of these sequences to support effective prenylation of Ydj1p and a Ydj1p-based thermotolerance phenotype, indicating that Cxx sequences can exhibit biologically relevant reactivity. While no prenylated Cxx proteins have been identified by mass spectrometry-based proteomics studies utilizing chemically modified prenyl donors, ${ }^{66-71}$ this may reflect multiple factors, including reduced reactivity with prenyl donor analogues used for proteomics analysis, low Cxx sequence reactivity or protein abundance, or mass spectrometry complications such as neutral loss or peptide oxidation. The subset of $\mathrm{Cxx}$ sequences derived from the human proteome that were examined in this work is less reactive than canonical CaaX sequences (e.g., the dns-GCLL peptide is $~ 40$-fold less reactive than dns-GCVLS), ${ }^{61}$ but the reactivity of dns-GCLL lies near the range established as viable for prenylation within a mammalian cell. ${ }^{72}$ Thus, prenylated yeast and human Cxx proteins remain an intriguing possibility with a significant number of proteins bearing Cxx-terminal sequences predicted in the human proteome (Table S6). In addition to the selectivity rules defining Cxx sequence reactivity with FTase with both FPP and GGPP prenyl donors, cell-based studies of novel prenylated Cxx sequences will be essential for defining the biological roles potentially played by these proteins and the expanding importance of prenylation within proteomes.

\section{Supplementary Material}

Refer to Web version on PubMed Central for supplementary material.

\section{ACKNOWLEDGMENTS}

The authors thank Dr. Avrom Caplan (City College of New York, New York, NY) for the anti-Ydj1p primary antibody and gratefully acknowledge Tongyin Zheng and Dr. Carlos Castañeda (Syracuse University) for assistance with mass spectrometry analysis of prenylated peptides. The Shimadzu LCMS-8040 mass spectrometer used in this work was partially supported by an equipment grant to Carlos Castañeda (Shimadzu Scientific Instruments).

Funding 
This work was funded by Syracuse University (J.L.H.) and grants from the National Institutes of Health (GM117148 to W.K.S. and GM132606 to W.K.S. and J.L.H.).

\section{ABBREVIATIONS}

\begin{tabular}{|c|c|}
\hline dns or dansyl & 5-(dimethylamino)naphthalene-1-sulfonyl \\
\hline ESI & electrospray ionization \\
\hline FPP & farnesyl diphosphate \\
\hline FTase & protein farnesyltransferase \\
\hline GGPP & geranylgeranyl diphosphate \\
\hline GGTase-I & protein geranylgeranyltransferase type I \\
\hline GGTase-II & protein geranylgeranyltransferase type II \\
\hline Hsp40 & heat shock protein 40 \\
\hline ICMT & isoprenylcysteine carboxyl methyltransferase \\
\hline LC-MS & liquid chromatography-mass spectrometry \\
\hline MAT & mating type locus \\
\hline PCR & polymerase chain reaction \\
\hline Rce1p & Ras converting enzyme 1 \\
\hline RP-HPLC & reverse-phase high-pressure liquid chromatography \\
\hline SC & synthetic complete agar plates \\
\hline SD & synthetic minimal medium agar plates \\
\hline TCEP & tris(2-carboxyethyl)phosphine \\
\hline UTR & untranslated region \\
\hline YPD & yeast rich medium agar plates \\
\hline
\end{tabular}

\section{REFERENCES}

(1). Mann M, and Jensen ON (2003) Proteomic analysis of posttranslational modifications. Nat. Biotechnol 21, 255-261. [PubMed: 12610572]

(2). Marshall CJ (1993) Protein prenylation: a mediator of protein-protein interactions. Science 259, 1865-1866. [PubMed: 8456312]

(3). Casey PJ, and Seabra MC (1996) Protein prenyltransferases. J. Biol. Chem 271, 5289-5292. [PubMed: 8621375]

(4). Zhang FL, and Casey PJ (1996) Protein prenylation: molecular mechanisms and functional consequences. Annu. Rev. Biochem 65, 241-269. [PubMed: 8811180]

(5). Benetka W, Koranda M, and Eisenhaber F (2006) Protein prenylation: An (almost) comprehensive overview on discovery, history, enzymology, and significance in physiology and disease. Monatsh. Chem 137, 1241. 
(6). Blanden MJ, Suazo KF, Hildebrandt ER, Hardgrove DS, Patel M, Saunders WP, Distefano MD, Schmidt WK, and Hougland JL (2018) Efficient farnesylation of an extended C-terminal C(x)3X sequence motif expands the scope of the prenylated proteome. J. Biol. Chem 293, 2770-2785. [PubMed: 29282289]

(7). Wang M, and Casey PJ (2016) Protein prenylation: unique fats make their mark on biology. Nat. Rev. Mol. Cell Biol 17, 110-122. [PubMed: 26790532]

(8). Lau HY, Tang J, Casey PJ, and Wang M (2017) Isoprenylcysteine carboxylmethyltransferase is critical for malignant transformation and tumor maintenance by all RAS isoforms. Oncogene 36, 3934-3942. [PubMed: 28192404]

(9). Feig LA, and Buchsbaum RJ (2002) Cell signaling: life or death decisions of ras proteins. Curr. Biol 12, R259-R261. [PubMed: 11937045]

(10). Bonni A, Brunet A, West AE, Datta SR, Takasu MA, and Greenberg ME (1999) Cell survival promoted by the Ras-MAPK signaling pathway by transcription-dependent and -independent mechanisms. Science 286, 1358-1362. [PubMed: 10558990]

(11). Casey PJ (1995) Protein lipidation in cell signaling. Science 268, 221-225. [PubMed: 7716512]

(12). Vantaggiato C, Formentini I, Bondanza A, Bonini C, Naldini L, and Brambilla R (2006) ERK1 and ERK2 mitogen-activated protein kinases affect Ras-dependent cell signaling differentially. J. Biol 5, 14. [PubMed: 16805921]

(13). Leung KF, Baron R, Ali BR, Magee AI, and Seabra MC (2007) Rab GTPases containing a CAAX motif are processed post-geranylgeranylation by proteolysis and methylation. J. Biol. Chem 282, 1487-1497. [PubMed: 17114793]

(14). Winter-Vann AM, and Casey PJ (2005) Post-prenylation-processing enzymes as new targets in oncogenesis. Nat. Rev. Cancer 5, 405-412. [PubMed: 15864282]

(15). Michaelson D, Ali W, Chiu VK, Bergo M, Silletti J, Wright L, Young SG, and Philips M (2005) Postprenylation CAAX processing is required for proper localization of Ras but not Rho GTPases. Mol. Biol. Cell 16, 1606-1616. [PubMed: 15659645]

(16). Solski PA, Helms W, Keely PJ, Su L, and Der CJ (2002) RhoA biological activity is dependent on prenylation but independent of specific isoprenoid modification. Cell Growth Differ. 13, 363373. [PubMed: 12193475]

(17). Roberts PJ, Mitin N, Keller PJ, Chenette EJ, Madigan JP, Currin RO, Cox AD, Wilson O, Kirschmeier P, and Der CJ (2008) Rho family GTPase modification and dependence on CAAX motif-signaled posttranslational modification. J. Biol. Chem 283, 25150-25163. [PubMed: 18614539]

(18). Hildebrandt ER, Cheng M, Zhao P, Kim JH, Wells L, and Schmidt WK (2016) A shunt pathway limits the CaaX processing of Hsp40 Ydj1p and regulates Ydj1p-dependent phenotypes. eLife 5, No. e15899. [PubMed: 27525482]

(19). Berger BM, Kim JH, Hildebrandt ER, Davis IC, Morgan MC, Hougland JL, and Schmidt WK (2018) Protein isoprenylation in yeast targets COOH-terminal sequences not adhering to the CaaX consensus. Genetics 210, 1301-1316. [PubMed: 30257935]

(20). Casey PJ, Thissen JA, and Moomaw JF (1991) Enzymatic modification of proteins with a geranylgeranyl isoprenoid. Proc. Natl. Acad. Sci. U. S. A 88, 8631-8635. [PubMed: 1924324]

(21). Caplin BE, Hettich LA, and Marshall MS (1994) Substrate characterization of the saccharomyces cerevisiae protein farnesyltransferase and type-I protein geranylgeranyltransferase. Biochim. Biophys. Acta, Protein Struct. Mol. Enzymol 1205, 39-48.

(22). Omer CA, Kral AM, Diehl RE, Prendergast GC, Powers S, Allen CM, Gibbs JB, and Kohl NE (1993) Characterization of recombinant human farnesyl-protein transferase: cloning, expression, farnesyl diphosphate binding, and functional homology with yeast prenyl-protein transferases. Biochemistry 32, 5167-5176. [PubMed: 8494894]

(23). Reiss Y, Seabra MC, Armstrong SA, Slaughter CA, Goldstein JL, and Brown MS (1991) Nonidentical subunits of $\mathrm{p} 21 \mathrm{H}$-ras farnesyltransferase. Peptide binding and farnesyl pyrophosphate carrier functions. J. Biol. Chem 266, 10672-10677. [PubMed: 2037606]

(24). Fu HW, and Casey PJ (1999) Enzymology and biology of CaaX protein prenylation. Recent Prog. Horm. Res 54, 315-342. [PubMed: 10548882] 
(25). Reid TS, Terry KL, Casey PJ, and Beese LS (2004) Crystallographic analysis of CaaX prenyltransferases complexed with substrates defines rules of protein substrate selectivity. J. Mol. Biol 343, 417-433. [PubMed: 15451670]

(26). Lane KT, and Beese LS (2006) Thematic review series: lipid posttranslational modifications. Structural biology of protein farnesyltransferase and geranylgeranyltransferase type I. J. Lipid Res 47, 681-699. [PubMed: 16477080]

(27). Maurer-Stroh S, Koranda M, Benetka W, Schneider G, Sirota FL, and Eisenhaber F (2007) Towards complete sets of farnesylated and geranylgeranylated proteins. PLoS Comput. Biol 3, No. e66. [PubMed: 17411337]

(28). Maurer-Stroh S, and Eisenhaber F (2005) Refinement and prediction of protein prenylation motifs. Genome Biol. 6, R55. [PubMed: 15960807]

(29). Hougland JL, Lamphear CL, Scott SA, Gibbs RA, and Fierke CA (2009) Context-dependent substrate recognition by protein farnesyltransferase. Biochemistry 48, 1691-701. [PubMed: 19199818]

(30). London N, Lamphear CL, Hougland JL, Fierke CA, and Schueler-Furman O (2011) Identification of a novel class of farnesylation targets by structure-based modeling of binding specificity. PLoS Comput. Biol 7, No. e1002170. [PubMed: 21998565]

(31). Hartman HL, Hicks KA, and Fierke CA (2005) Peptide specificity of protein prenyltransferases is determined mainly by reactivity rather than binding affinity. Biochemistry 44, 15314-15324. [PubMed: 16285735]

(32). Moores SL, Schaber MD, Mosser SD, Rands E, O’Hara MB, Garsky VM, Marshall MS, Pompliano DL, and Gibbs JB (1991) Sequence dependence of protein isoprenylation. J. Biol. Chem 266, 14603-14610. [PubMed: 1860864]

(33). Schaber MD, O’Hara MB, Garsky VM, Mosser SC, Bergstrom JD, Moores SL, Marshall MS, Friedman PA, Dixon RA, and Gibbs JB (1990) Polyisoprenylation of Ras in vitro by a farnesylprotein transferase. J. Biol. Chem 265, 14701-14704. [PubMed: 2203759]

(34). Hancock JF, Cadwallader K, Paterson H, and Marshall CJ (1991) A CAAX or a CAAL motif and a second signal are sufficient for plasma membrane targeting of ras proteins. EMBO J. 10, 40334039. [PubMed: 1756714]

(35). Gao J, Liao J, and Yang GY (2009) CAAX-box protein, prenylation process and carcinogenesis. Am. J. Transl. Res 1, 312-325. [PubMed: 19956441]

(36). Hougland JL, Gangopadhyay SA, and Fierke CA (2012) Expansion of protein farnesyltransferase specificity using "tunable" active site interactions: development of bioengineered prenylation pathways. J. Biol. Chem 287, 38090-38100. [PubMed: 22992747]

(37). Hougland JL, Hicks KA, Hartman HL, Kelly RA, Watt TJ, and Fierke CA (2010) Identification of novel peptide substrates for protein farnesyltransferase reveals two substrate classes with distinct sequence selectivities. J. Mol. Biol 395, 176-190. [PubMed: 19878682]

(38). Long SB, Casey PJ, and Beese LS (1998) Cocrystal structure of protein farnesyltransferase complexed with a farnesyl diphosphate substrate. Biochemistry 37, 9612-9618. [PubMed: 9657673]

(39). Taylor JS, Reid TS, Terry KL, Casey PJ, and Beese LS (2003) Structure of mammalian protein geranylgeranyltransferase type-I. EMBO J. 22, 5963-5974. [PubMed: 14609943]

(40). Gangopadhyay SA, Losito EL, and Hougland JL (2014) Targeted reengineering of protein geranylgeranyltransferase type I selectivity functionally implicates active-site residues in proteinsubstrate recognition. Biochemistry 53, 434-446. [PubMed: 24344934]

(41). Terry KL, Casey PJ, and Beese LS (2006) Conversion of protein farnesyltransferase to a geranylgeranyltransferase. Biochemistry 45, 9746-9755. [PubMed: 16893176]

(42). Yokoyama K, Zimmerman K, Scholten J, and Gelb MH (1997) Differential prenyl pyrophosphate binding to mammalian protein geranylgeranyltransferase-I and protein farnesyltransferase and its consequence on the specificity of protein prenylation. J. Biol. Chem 272, 3944-3952. [PubMed: 9020098]

(43). Chan RK, and Otte CA (1982) Isolation and genetic analysis of Saccharomyces cerevisiae mutants supersensitive to G1 arrest by a factor and alpha factor pheromones. Mol. Cell. Biol 2, 11-20. [PubMed: 7050665] 
(44). Michaelis S, and Herskowitz I (1988) The a-factor pheromone of Saccharomyces cerevisiae is essential for mating. Mol. Cell. Biol 8, 1309-1318. [PubMed: 3285180]

(45). Chen P, Sapperstein SK, Choi JD, and Michaelis S (1997) Biogenesis of the Saccharomyces cerevisiae mating pheromone a-factor. J. Cell Biol 136, 251-269. [PubMed: 9015298]

(46). Shoemaker DD, Lashkari DA, Morris D, Mittmann M, and Davis RW (1996) Quantitative phenotypic analysis of yeast deletion mutants using a highly parallel molecular bar-coding strategy. Nat. Genet 14, 450-456. [PubMed: 8944025]

(47). Oldenburg KR, Vo KT, Michaelis S, and Paddon C (1997) Recombination-mediated PCRdirected plasmid construction in vivo in yeast. Nucleic Acids Res. 25, 451-452. [PubMed: 9016579]

(48). Schmidt WK, Tam A, Fujimura-Kamada K, and Michaelis S (1998) Endoplasmic reticulum membrane localization of Rce1p and Ste24p, yeast proteases involved in carboxyl-terminal CAAX protein processing and amino-terminal a-factor cleavage. Proc. Natl. Acad. Sci. U. S. A 95, 11175-11180. [PubMed: 9736709]

(49). Sikorski RS, and Hieter P (1989) A system of shuttle vectors and yeast host strains designed for efficient manipulation of DNA in Saccharomyces cerevisiae. Genetics 122, 19-27. [PubMed: 2659436]

(50). Elble R (1992) A simple and efficient procedure for transformation of yeasts. BioTechniques 13, 18-20. [PubMed: 1503765]

(51). Firth AE, and Patrick WM (2008) GLUE-IT and PEDELAA: new programmes for analyzing protein diversity in randomized libraries. Nucleic Acids Res. 36 (WebServer issue), W281W285. [PubMed: 18442989]

(52). Kim S, Lapham A, Freedman C, Reed T, and Schmidt W (2005) Yeast as a tractable genetic system for functional studies of the insulin-degrading enzyme. J. Biol. Chem 280, 27481-27490. [PubMed: 15944156]

(53). Caplan AJ, Tsai J, Casey PJ, and Douglas MG (1992) Farnesylation of YDJ1p is required for function at elevated growth temperatures in Saccharomyces cerevisiae. J. Biol. Chem 267, 18890-18895. [PubMed: 1527016]

(54). Trueblood CE, Boyartchuk VL, Picologlou EA, Rozema D, Poulter CD, and Rine J (2000) The $\mathrm{CaaX}$ proteases, Afc1p and Rcelp, have overlapping but distinct substrate specificities. Mol. Cell. Biol 20, 4381-4392. [PubMed: 10825201]

(55). Wang YC, Dozier JK, Beese LS, and Distefano MD (2014) Rapid analysis of protein farnesyltransferase substrate specificity using peptide libraries and isoprenoid diphosphate analogues. ACS Chem. Biol 9, 1726-1735. [PubMed: 24841702]

(56). Leung KF, Baron R, and Seabra MC (2006) Thematic review series: lipid posttranslational modifications. geranylgeranylation of Rab GTPases. J. Lipid Res 47, 467-475. [PubMed: 16401880]

(57). Boys BL, Kuprowski MC, Noel JJ, and Konermann L (2009) Protein oxidative modifications during electrospray ionization: solution phase electrochemistry or corona discharge-induced radical attack? Anal. Chem 81, 4027-4034. [PubMed: 19374432]

(58). Reid TS, Long SB, and Beese LS (2004) Crystallographic analysis reveals that anticancer clinical candidate L-778,123 inhibits protein farnesyltransferase and geranylgeranyltransferase-I by different binding modes. Biochemistry 43, 9000-9008. [PubMed: 15248757]

(59). Pompliano DL, Gomez RP, and Anthony NJ (1992) Intramolecular fluorescence enhancement: a continuous assay of Ras farnesyl:protein transferase. J. Am. Chem. Soc 114, 7945-7946.

(60). Cassidy PB, Dolence JM, and Poulter CD (1995) Continuous fluorescence assay for protein prenyltransferases. Methods Enzymol. 250, 30-43. [PubMed: 7651159]

(61). Reigard SA, Zahn TJ, Haworth KB, Hicks KA, Fierke CA, and Gibbs RA (2005) Interplay of isoprenoid and peptide substrate specificity in protein farnesyltransferase. Biochemistry 44, 11214-11223. [PubMed: 16101305]

(62). Jennings BC, Danowitz AM, Wang YC, Gibbs RA, Distefano MD, and Fierke CA (2016) Analogs of farnesyl diphosphate alter CaaX substrate specificity and reactions rates of protein farnesyltransferase. Bioorg. Med. Chem. Lett 26, 1333-1336. [PubMed: 26803203] 
(63). Troutman JM, Andres DA, and Spielmann HP (2007) Protein farnesyl transferase target selectivity is dependent upon peptide stimulated product release. Biochemistry 46, 11299-11309. [PubMed: 17877368]

(64). Subramanian T, Liu S, Troutman JM, Andres DA, and Spielmann HP (2008) Protein farnesyltransferase-catalyzed isoprenoid transfer to peptide depends on lipid size and shape, not hydrophobicity. ChemBioChem 9, 2872-2882. [PubMed: 18985644]

(65). Hightower KE, Casey PJ, and Fierke CA (2001) Farnesylation of nonpeptidic thiol compounds by protein farnesyltransferase. Biochemistry 40, 1002-1010. [PubMed: 11170422]

(66). Storck EM, Morales-Sanfrutos J, Serwa RA, Panyain N, Lanyon-Hogg T, Tolmachova T, Ventimiglia LN, Martin-Serrano J, Seabra MC, Wojciak-Stothard B, and Tate EW (2019) Dual chemical probes enable quantitative system-wide analysis of protein prenylation and prenylation dynamics. Nat. Chem 11, 552-561. [PubMed: 30936521]

(67). Suazo KF, Schaber C, Palsuledesai CC, Odom John AR, and Distefano MD (2016) Global proteomic analysis of prenylated proteins in Plasmodium falciparum using an alkyne-modified isoprenoid analogue. Sci. Rep 6, 38615. [PubMed: 27924931]

(68). Wang YC, and Distefano MD (2016) Synthetic isoprenoid analogues for the study of prenylated proteins: Fluorescent imaging and proteomic applications. Bioorg. Chem 64, 59-65. [PubMed: 26709869]

(69). Kho Y, Kim SC, Jiang C, Barma D, Kwon SW, Cheng J, Jaunbergs J, Weinbaum C, Tamanoi F, Falck J, and Zhao Y (2004) A tagging-via-substrate technology for detection and proteomics of farnesylated proteins. Proc. Natl. Acad. Sci. U. S. A 101, 12479-12484. [PubMed: 15308774]

(70). Stein V, Kubala MH, Steen J, Grimmond SM, and Alexandrov K (2015) Towards the systematic mapping and engineering of the protein prenylation machinery in Saccharomyces cerevisiae. PLoS One 10, No. e0120716. [PubMed: 25768003]

(71). Nguyen UT, Guo Z, Delon C, Wu Y, Deraeve C, Franzel B, Bon RS, Blankenfeldt W, Goody RS, Waldmann H, Wolters D, and Alexandrov K (2009) Analysis of the eukaryotic prenylome by isoprenoid affinity tagging. Nat. Chem. Biol 5, 227-235. [PubMed: 19219049]

(72). Flynn SC, Lindgren DE, and Hougland JL (2014) Quantitative determination of cellular farnesyltransferase activity: towards defining the minimum substrate reactivity for biologically relevant protein farnesylation. ChemBioChem 15, 2205-2210. [PubMed: 25182009] 


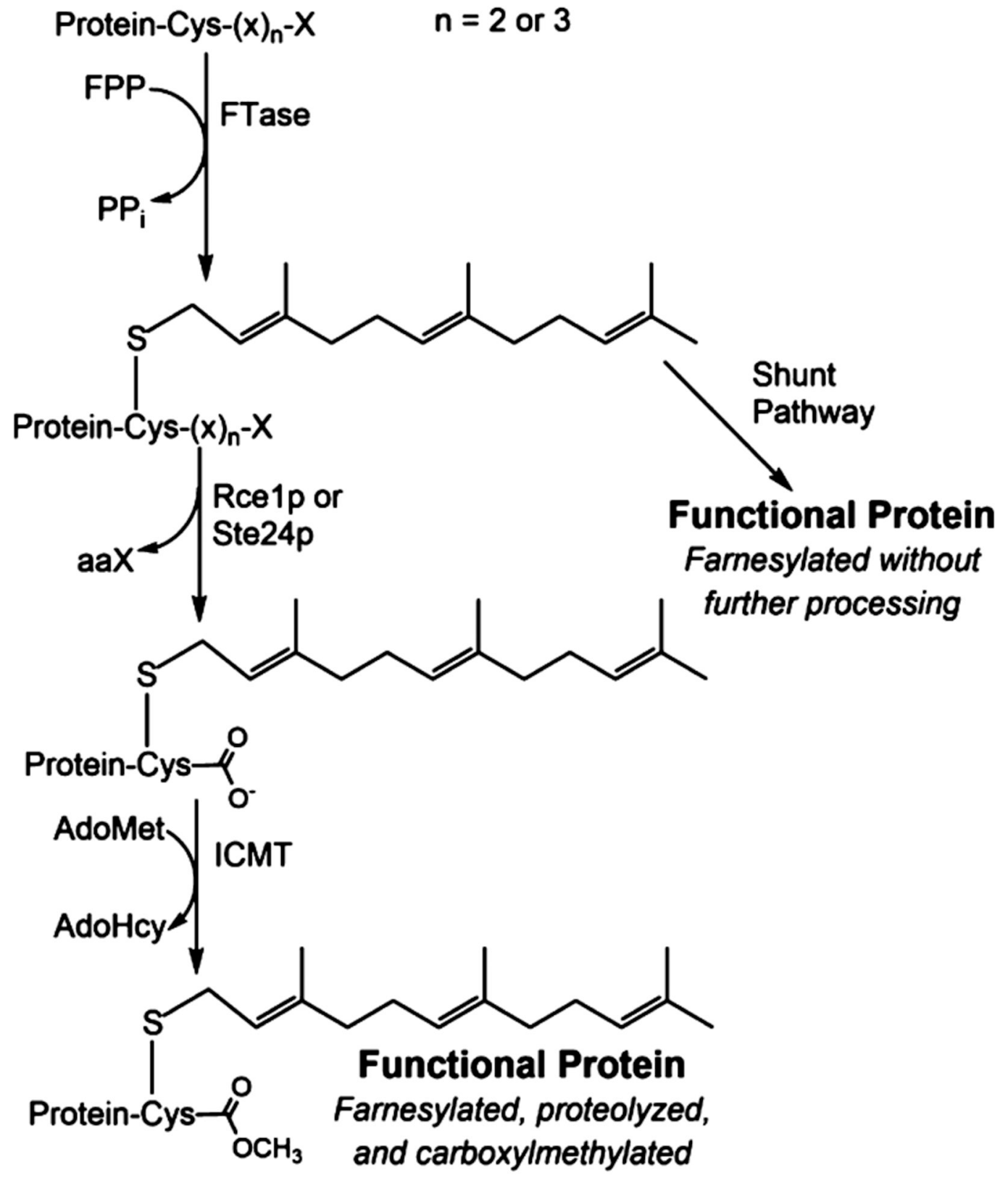

Scheme 1. Protein Farnesylation and Processing Pathway

aFTase catalyzes the covalent attachment of a 15-carbon farnesyl group to proteins terminating in $\mathrm{CaaX}(n=2)$ or $\mathrm{C}(\mathrm{x})_{3} \mathrm{X}(n=3)$ sequences, with subsequent proteolytic and carboxymethylation steps required for many but not all farnesylated proteins. Modification of CaaX $(n=2)$ sequences is well-documented in various organisms; modification of $\mathrm{C}(\mathrm{x})_{3} \mathrm{X}$ sequences $(n=3)$ has not yet been verified for a naturally occurring protein but has been demonstrated using an in vivo reporter. 
a)

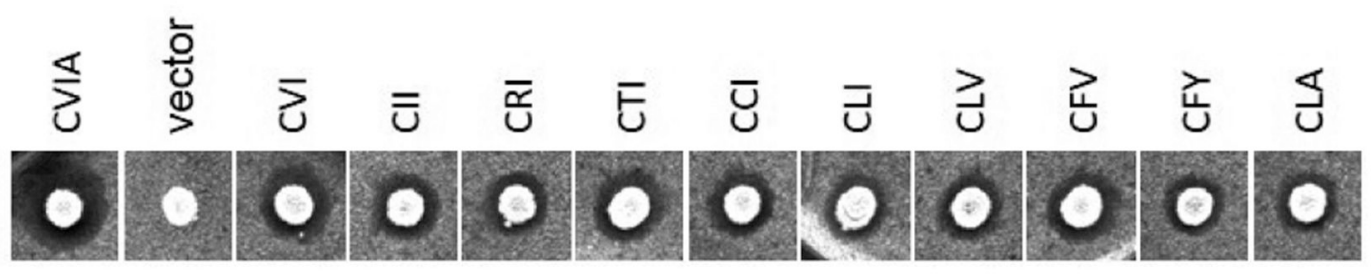

b)
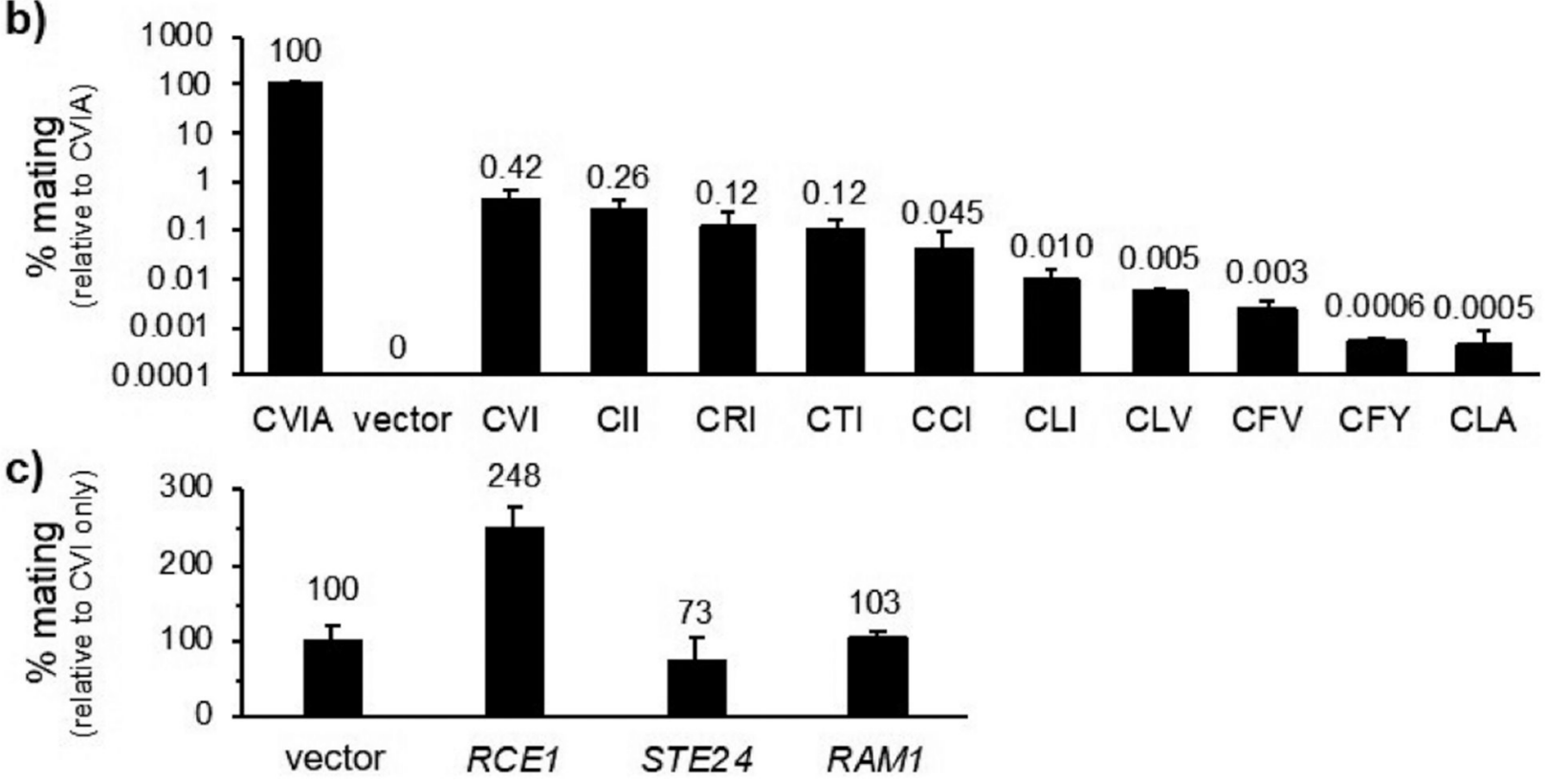

Figure 1.

Phenotypes of a-factor Cxx variants. (a) The spot halo assay is a highly sensitive and qualitative measure of a-factor production. SM2331 (MATa mfa1 $\mathrm{mfa}$ ) was transformed with plasmids encoding a-factor mutants or a vector (CEN LEU2), resultant strains cultured as spots on YPD for $48 \mathrm{~h}$ at $30^{\circ} \mathrm{C}$, and spots replica transferred onto a thin lawn of RC757 (MATa sst2-1). A zone of growth inhibition (i.e., halo) indicates pheromone production. (b) The mating assay is used for relative measures of a-factor production. The MATa strains described in panel a were tested in combination with IH1793 (MATa 1ys1). All values are relative to diploid production (i.e., mating events) observed with MATa yeast expressing wild type a-factor (CVIA; set to $100 \%$ mating efficiency). Mating values were determined from two experiments in which each sample was minimally evaluated in duplicate. (c) The mating efficiencies for a-factor-CVI were determined as described for panel $b$ under conditions where the indicated CaaX-modifying enzyme was overexpressed via a $2 \mu$ plasmid. All values are relative to diploid production (i.e., mating events) observed with an empty vector $2 \mu$ plasmid. Values represent the average of three biological replicates. RCE1 encodes the Ras converting enzyme 1 (Rce1p) CaaX protease. STE24 encodes sterile protein 24 (Ste24p). Both Rce1p and Ste24p can cleave the a-factor CaaX motif. RAM1 encodes the FTase $\beta$ subunit, whose overexpression improves FTase activity in some yeast strains. ${ }^{54}$ 
a)

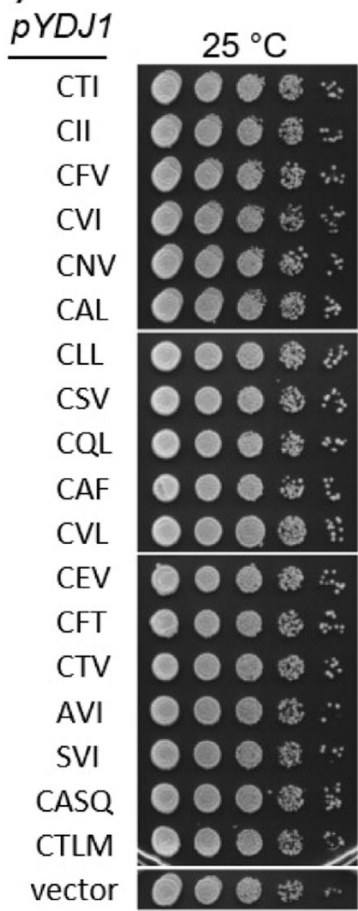

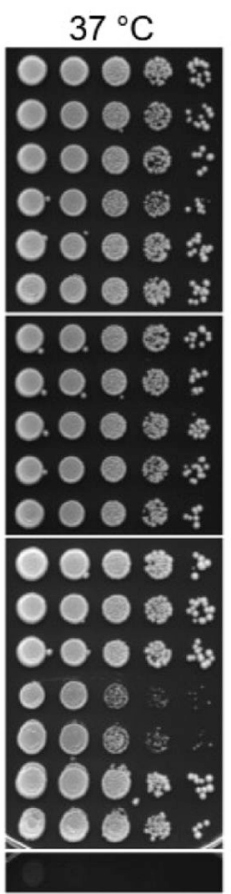

b)

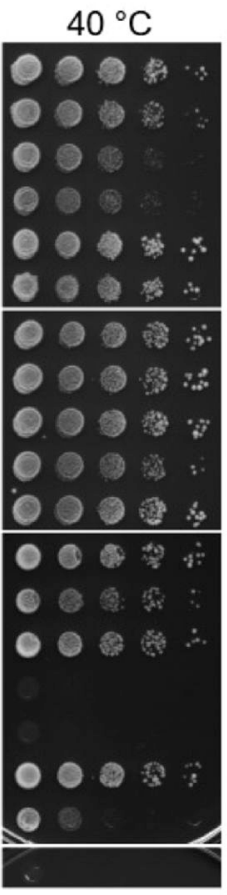

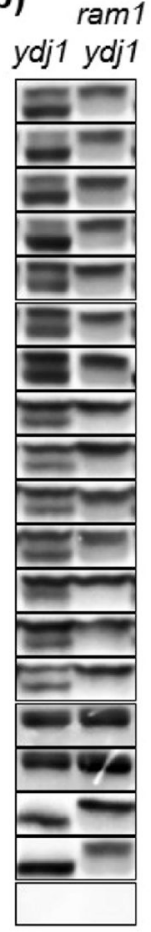

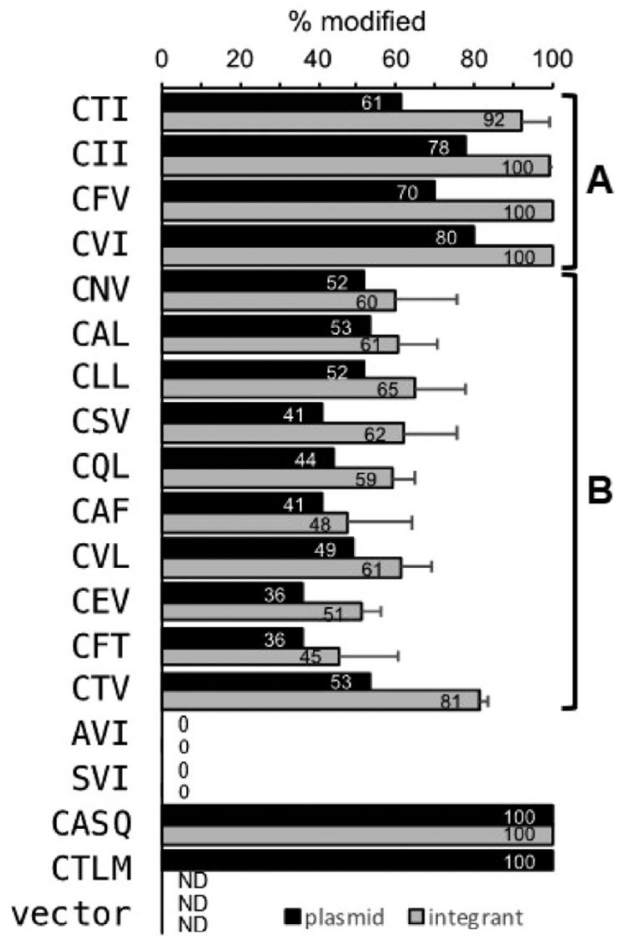

Figure 2.

Phenotypes and isoprenylation status of Ydj1p Cxx variants. (a) The indicated Ydj1p Cxx variants were transformed into the yWS2544 $\left(y d j 1:: N A T^{R}\right)$ strain background and assessed for farnesyl-dependent biological activity using a thermotolerance assay. At $37^{\circ} \mathrm{C}$, yeast cannot grow in the absence of Ydj1p (i.e., vector). At $40{ }^{\circ} \mathrm{C}$, yeast cannot grow in the absence of farnesylated Ydj1p (i.e., AVI and SVI), and shunted Ydj1p (i.e., CASQ) supports better growth than cleaved and carboxylmethylated Ydj1p (i.e., CTLM); shunted refers to sequences that are farnesylated but not additionally modified (see Scheme 1). Each set of spots represents a 10-fold dilution series derived from a saturated culture initially grown in selective medium. (b) The mobility shift assay assesses the prenylation level of each Ydj1p Cxx variant. It relies on the observation that unmodified and farnesylated Ydj1p can be separated by SDS-PAGE, with the farnesylated species exhibiting a counterintuitive lower apparent molecular mass relative to that of the unmodified form. Whole cell extracts were prepared as two sets and then analyzed by SDS-PAGE and anti-Ydj1p immunoblotting. One set was prepared from yWS2544 and yWS2542 (ram1::KAN $N^{R}$ dj1 $\left.: N A T^{R}\right)$ strain backgrounds that were transformed with the same plasmids used for thermotolerance testing (see panel a); $R A M 1$ encodes the FTase $\beta$ subunit, and its absence eliminates endogenous FTase activity. Bands associated with the yWS2544 extracts shown in panel b were quantified using ImageJ, and these values were used to plot the percent modification for each Cxx sequence (black bars, single biological replicate). A second set of extracts was prepared and analyzed from strains into which Ydj1p Cxx variants had been integrated into the $y d j 1 \Delta$ locus of yWS2544 [gray bars, three technical replicates (see Figure S2)]. ND means not determined. (A) Cxx sequences initially identified using a-factor reporter and 
subsequently transferred onto Ydj1p. (B) Cxx sequences directly identified using Ydj1p reporter. 
a)
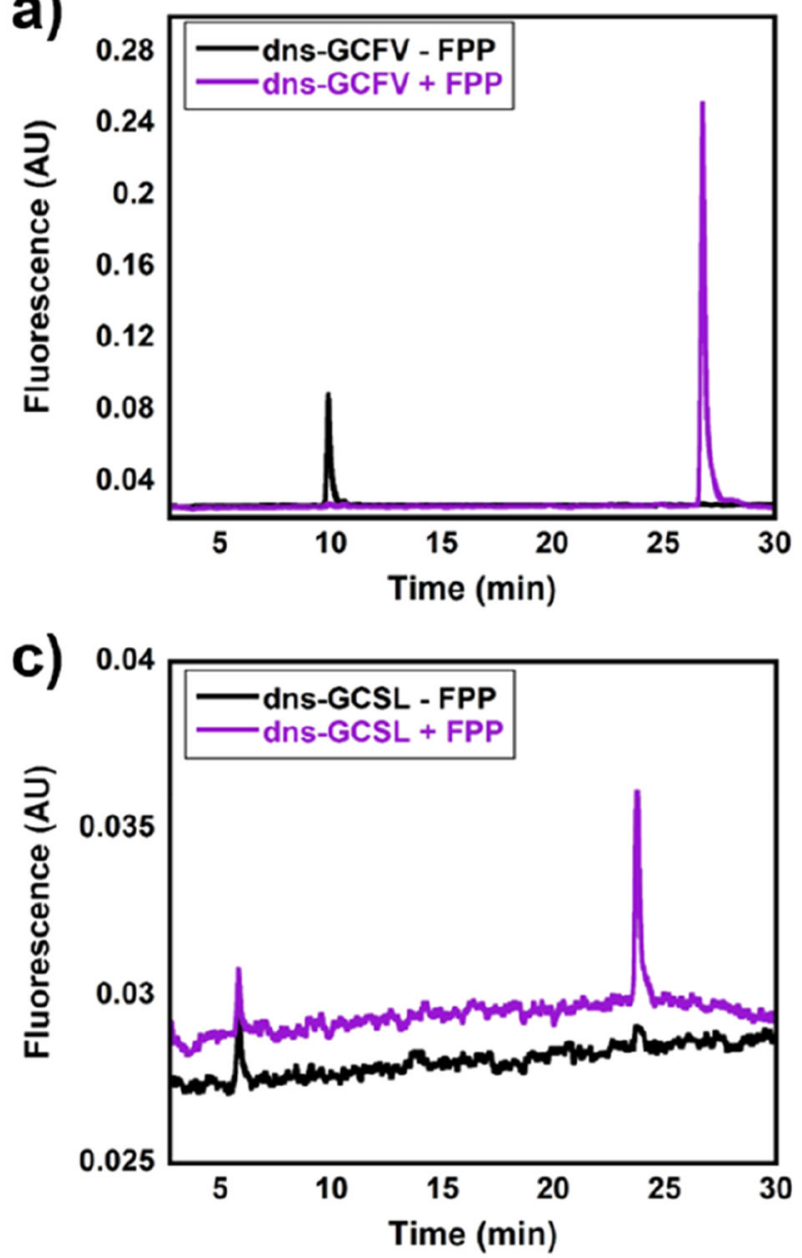
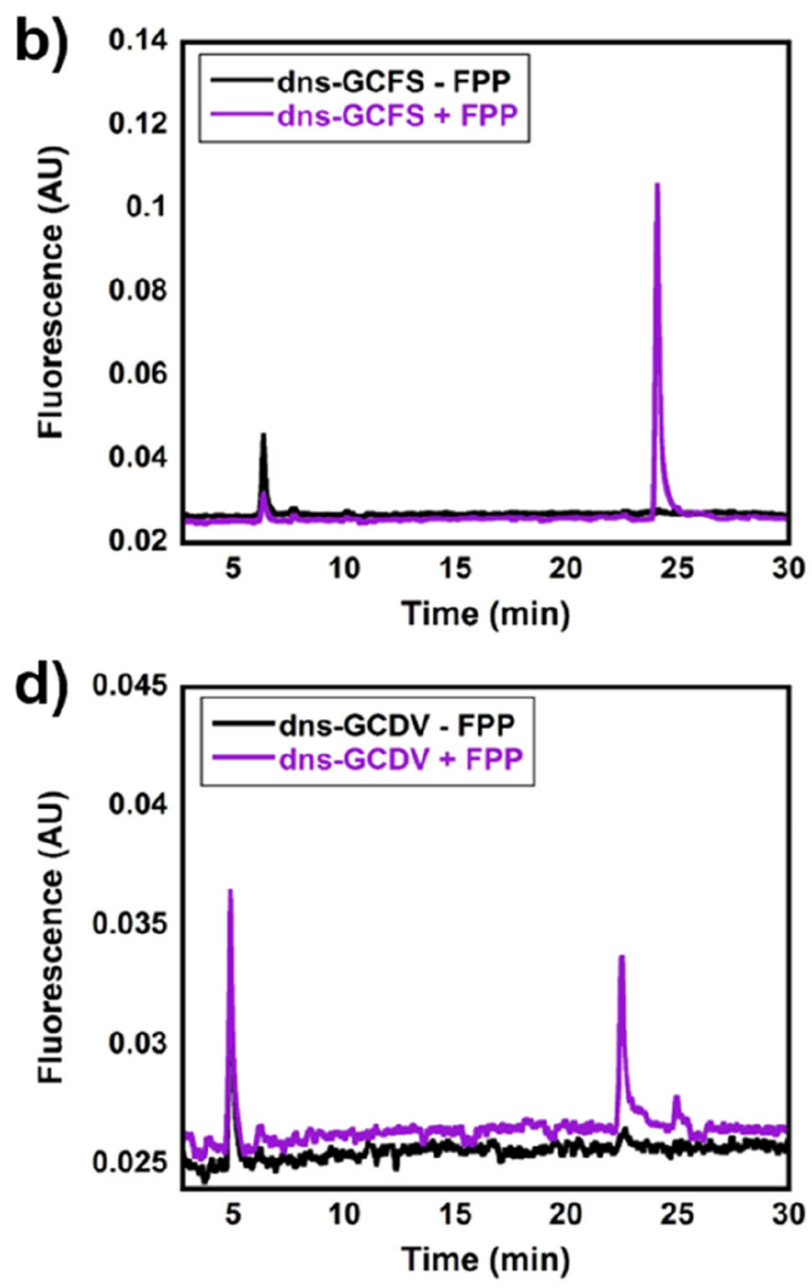

Figure 3.

FTase-catalyzed farnesylation of Cxx peptides confirmed by RP-HPLC analysis: (a) dnsGCFV, (b) dns-GCFS, (c) dns-GCSL, and (d) dns-GCDV. Purple and black lines denote reactions with and without $10 \mu \mathrm{M}$ FPP, respectively. Reactions and RP-HPLC analysis were carried out as described in Materials and Methods. 
a)
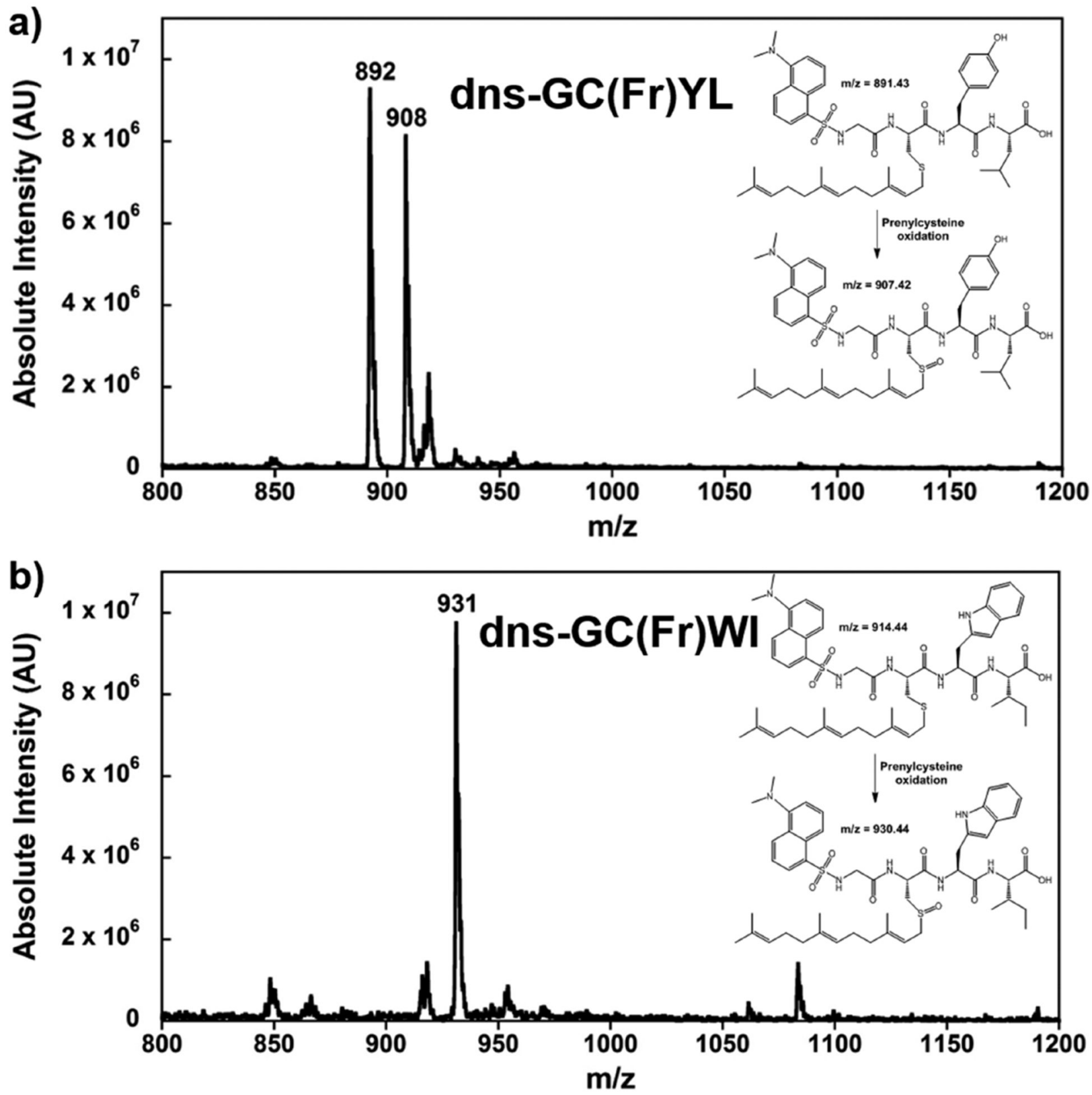

Figure 4.

LC-MS confirmation of FTase-catalyzed dns-GCxx peptide farnesylation. (a) LC-MS analysis of farnesylated dns-GCYL, with peaks at $\mathrm{m} / z 892$ and 908 corresponding to nonoxidized and oxidized farnesylated peptide, respectively. (b) LC-MS analysis of farnesylated dns-GCWI, with a peak at $\mathrm{m} / z 931$ representing the oxidized farnesylated peptide. (Fr) denotes the farnesylation of a cysteine side chain. 

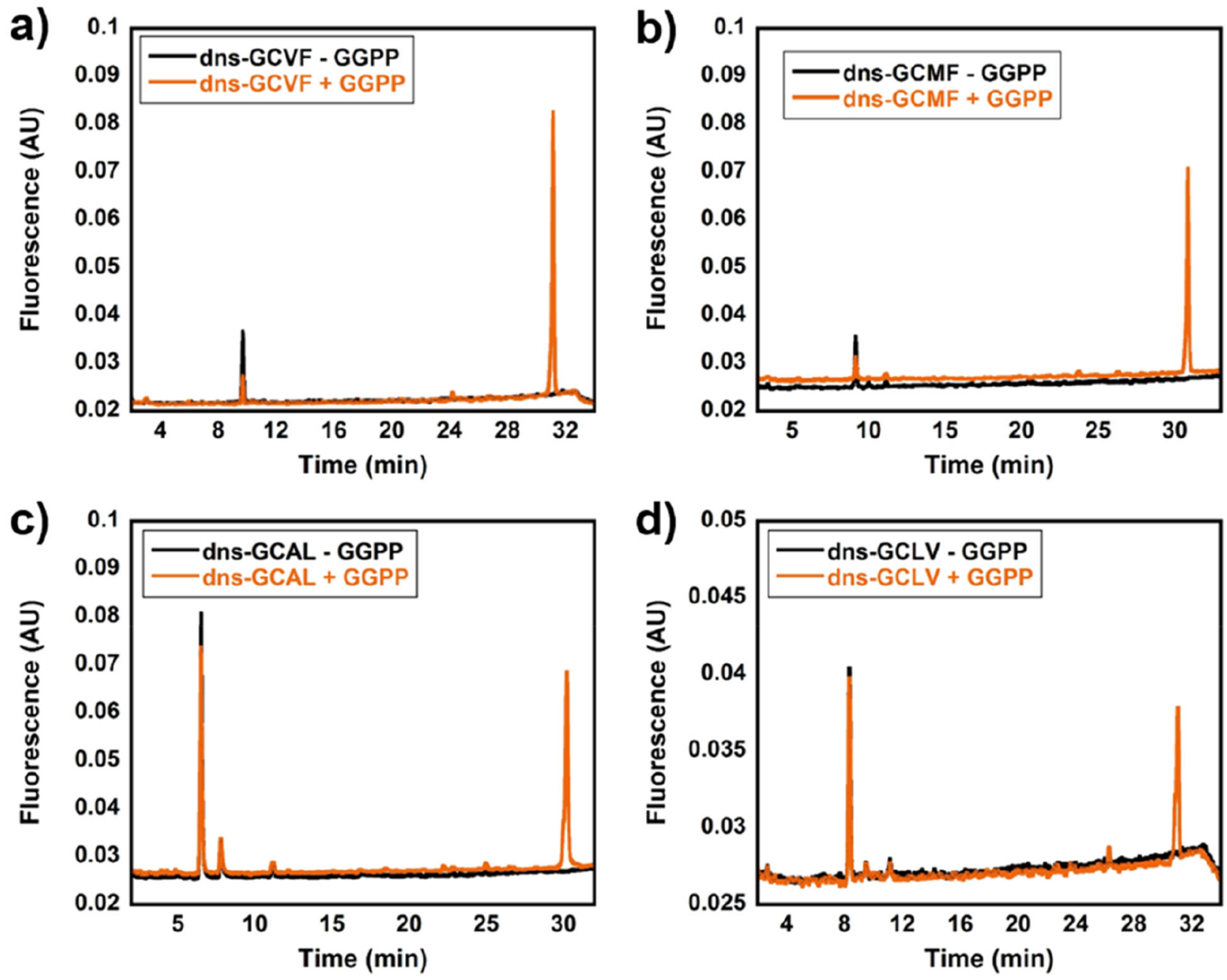

Figure 5.

FTase-catalyzed geranylgeranylation of dns-GCxx peptides: (a) dns-GCVF, (b) dns-GCMF, (c) dns-GCAL, and (d) dns-GCLV. Orange and black lines denote reactions with and without $10 \mu \mathrm{M}$ GGPP, respectively. Reactions and RP-HPLC analysis were carried out as described in Materials and Methods. 
a)

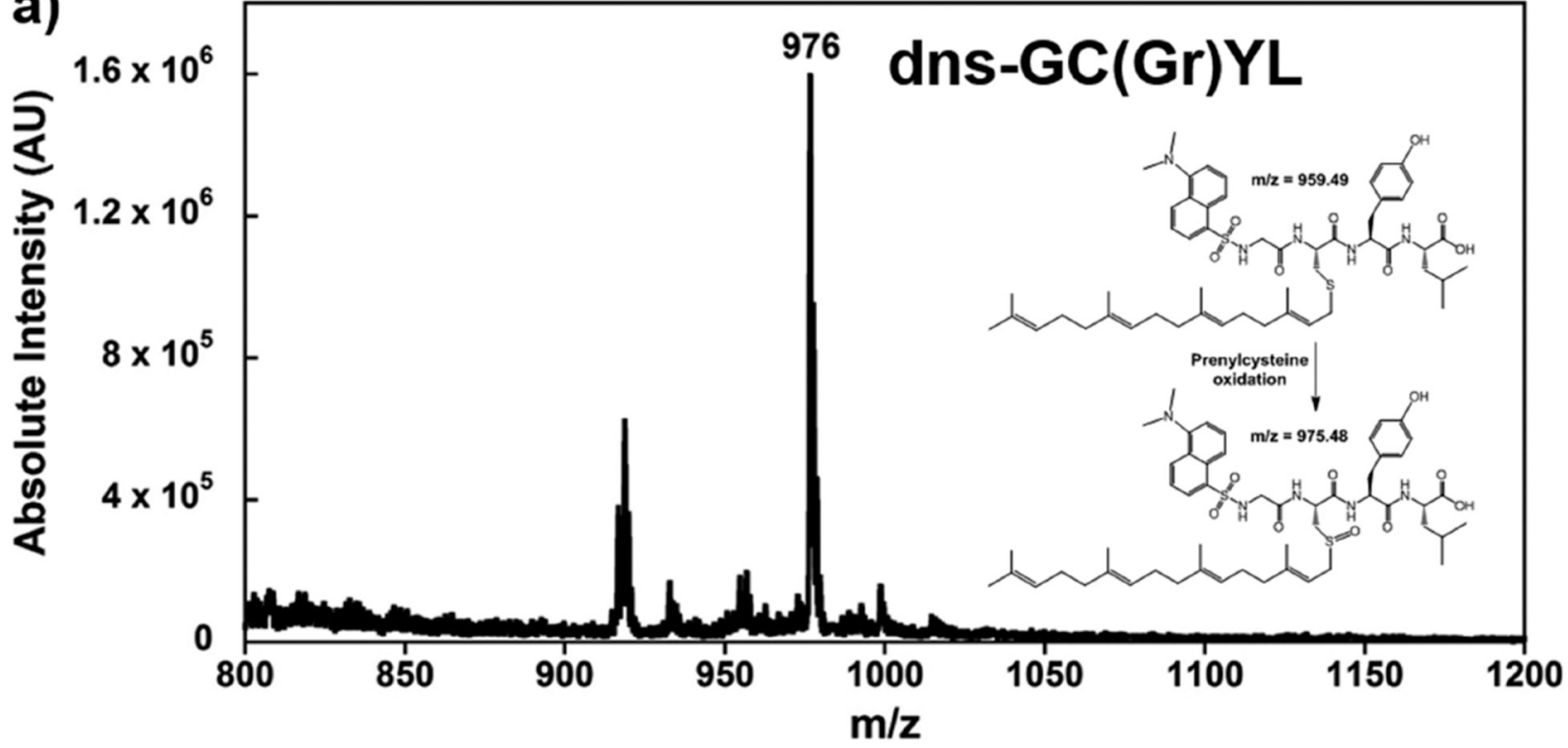

b) $3 \times 10^{6}$

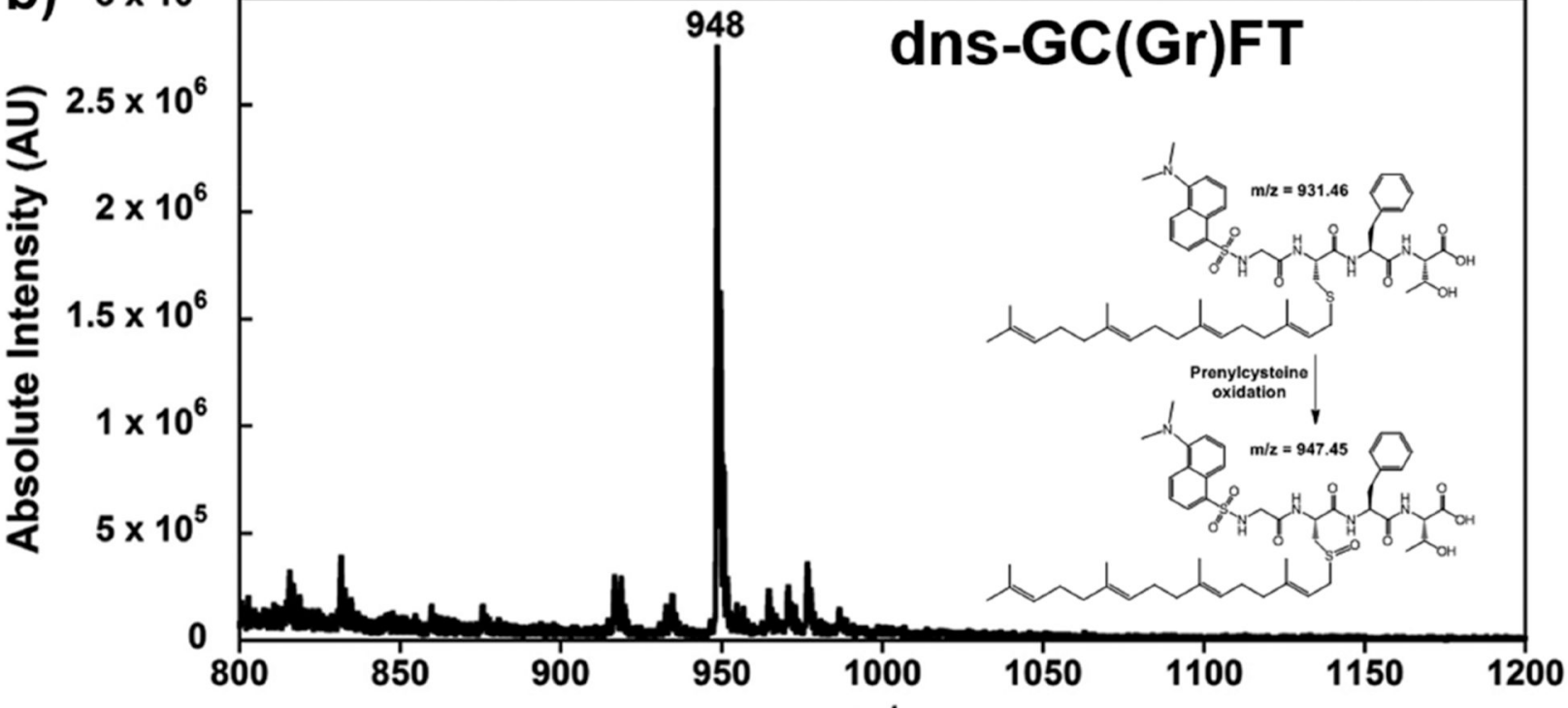

Figure 6.

LC-MS confirmation of FTase-catalyzed dns-GCxx peptide geranylgeranylation. (a) LC-MS analysis of geranylgeranylated dns-GCYL, with a peak at $\mathrm{m} / \mathrm{z} 976$ corresponding to the oxidized geranylgeranylated peptide. (b) LC-MS analysis of geranylgeranylated dns-GCFT, with a peak at $m / z 948$ representing the oxidized geranylgeranylated peptide. (Gr) denotes the geranylgeranylation of a cysteine side chain. 

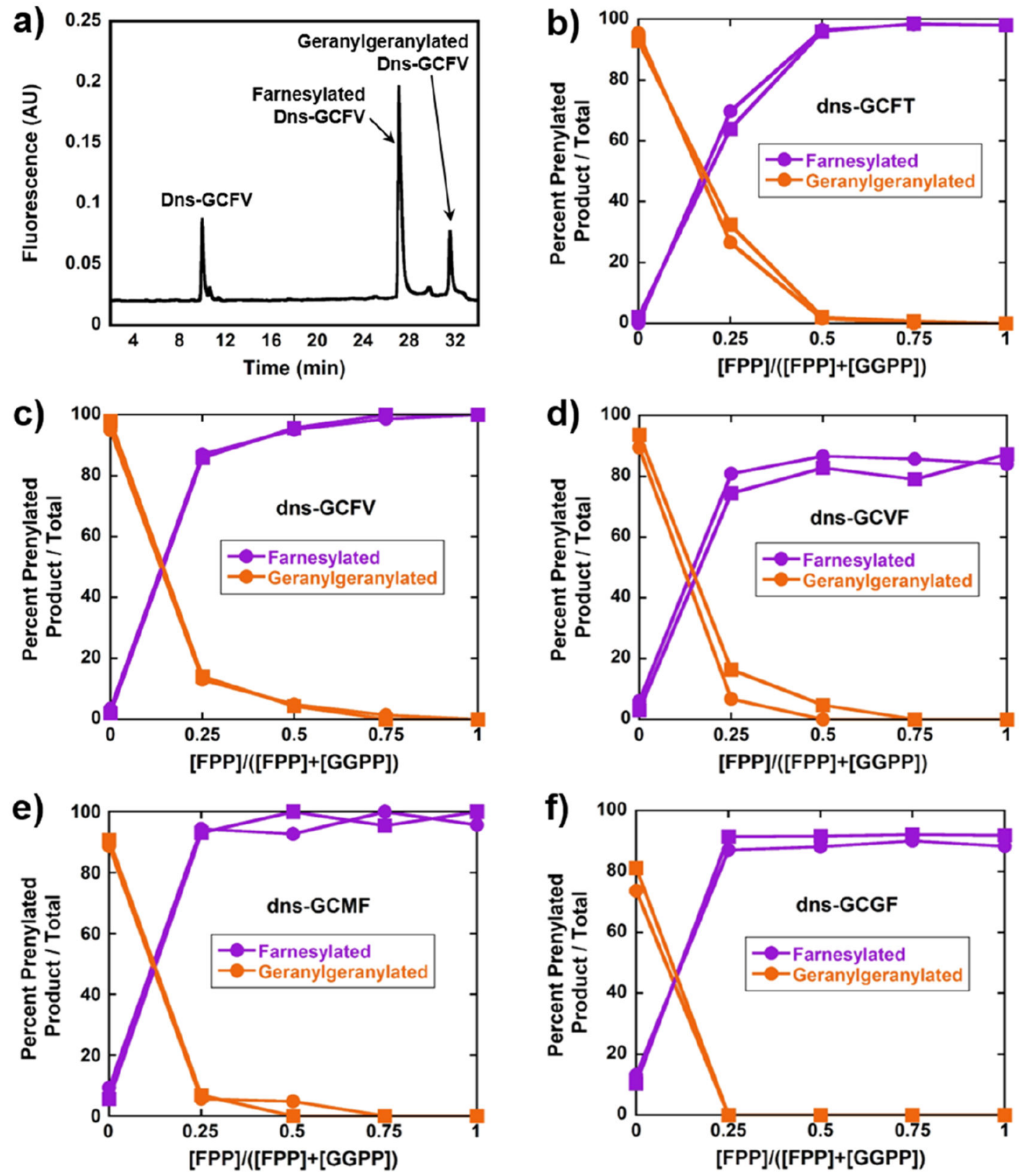

Figure 7.

Prenyl donor competition reveals the FTase preference for FPP over GGPP for modifying dns-GCxx peptides. (a) Representative chromatogram for a prenyl donor competition experiment with the dns-GCFV peptide and a 25:75 FPP:GGPP ratio. (b) Product distribution for dns-GCFT. (c) Product distribution for dns-GCFV. (d) Product distribution for dns-GCVF. (e) Product distribution for dns-GCMF. (f) Product distribution for dnsGCGF. Purple and orange lines and symbols denote farnesylated and geranylgeranylated products, respectively. Each plot represents two independent trials per peptide reaction. Reactions were performed and analyzed as described in Materials and Methods. 
Table 1.

Reactivities of Cxx Peptides with Mammalian FTase and Prenyl Donors ${ }^{a, b}$

\begin{tabular}{|c|c|c|c|}
\hline \multicolumn{4}{|c|}{ Complete Prenylation by Both Prenyl Donors (three total) $b$} \\
\hline $\mathrm{CFT}^{c}$ & $\mathrm{CFV}^{d}$ & $\mathrm{CMF}$ & \\
\hline \multicolumn{4}{|c|}{ Complete Prenylation with FPP; Partial Prenylation with GGPP (22 total) } \\
\hline $\mathrm{CAF}^{c}$ & CIL & CQA & $\mathrm{CVL}^{c}$ \\
\hline $\mathrm{CAL}^{c}$ & $\mathrm{CLL}^{c}$ & $\mathrm{CQL}^{c}$ & CWF \\
\hline CAV & $\mathrm{CLV}^{d}$ & CQV & CWI \\
\hline $\mathrm{CEV}^{c}$ & $\mathrm{CNV}^{c}$ & CSI & CYL \\
\hline CFS & CPI & $\mathrm{CSV}^{c}$ & \\
\hline $\mathrm{CII}^{d}$ & CPV & $\mathrm{CTV}^{c}$ & \\
\hline \multicolumn{4}{|c|}{ Complete Prenylation with FPP; No Prenylation with GGPP (1 total) $b$} \\
\hline \multicolumn{4}{|l|}{ CGI } \\
\hline \multicolumn{4}{|c|}{ Complete Prenylation with GGPP; Partial Prenylation with FPP ( 2 total $) b$} \\
\hline CGF & $\mathrm{CVF}$ & & \\
\hline \multicolumn{4}{|c|}{ Partial Prenylation with FPP and GGPP (11 total $)^{b}$} \\
\hline $\mathrm{CEF}$ & CLP & CSY & CVM \\
\hline $\mathrm{CHF}$ & CPL & CTS & CVY \\
\hline CLG & CSF & CVG & \\
\hline \multicolumn{4}{|c|}{ Partial Prenylation with FPP; No Prenylation with GGPP (25 total) $b$} \\
\hline CAG & CIE & $\mathrm{CPH}$ & CST \\
\hline CAP & CIQ & CPT & $\mathrm{CTH}$ \\
\hline CDI & CKI & CRL & CTP \\
\hline $\mathrm{CDV}$ & CKV & CRV & CVK \\
\hline CEG & CLD & CSA & \\
\hline CEY & CLK & CSL & \\
\hline CHP & $\mathrm{CNL}$ & CSQ & \\
\hline \multicolumn{4}{|c|}{ Nonreactive with Either Prenyl Donor (21 total) $b$} \\
\hline $\mathrm{CDP}$ & CNR & CQS & CSK \\
\hline $\mathrm{CGV}$ & CPG & CRD & CSS \\
\hline $\mathrm{CKH}$ & CPK & CRE & CTE \\
\hline CKK & CPP & CRF & \\
\hline CKP & CPR & CRQ & \\
\hline CKS & CPY & CSG & \\
\hline \multicolumn{4}{|c|}{ Peptide Sequences from a-Factor Screen That Were Not Tested ( 7 total) } \\
\hline $\mathrm{CVI}^{d}$ & $\mathrm{CTI}^{d}$ & $\mathrm{CLI}^{d}$ & $\mathrm{CLA}^{d}$ \\
\hline $\mathrm{CRI}^{d}$ & $\mathrm{CCI}^{d}$ & $\mathrm{CFY}^{d}$ & \\
\hline
\end{tabular}

Biochemistry. Author manuscript; available in PMC 2020 June 23. 
${ }^{a}$ Sequences were analyzed in the context of the indicated dns-GCxx peptide; each dns-GCxx peptide ( $\left.3 \mu \mathrm{M}\right)$ was reacted with FTase $(200 \mathrm{nM})$ and FPP or GGPP $(10 \mu \mathrm{M})$, and products were analyzed by RP-HPLC as described in Materials and Methods.

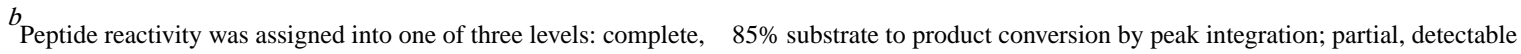
substrate to product conversion ( $\leq 84 \%$ ); or no detectable product.

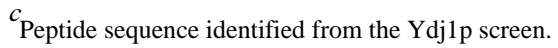

${ }^{d}$ Peptide sequence identified from the a-factor screen. 
Table 2.

Steady-State Reactivity of dns-GCxx Peptides Catalyzed by FTase ${ }^{a}$

\begin{tabular}{ccl}
\hline & \multicolumn{2}{c}{$\boldsymbol{k}_{\text {cat }} / \boldsymbol{K}_{\mathbf{m}}\left(\mathbf{M}^{-\mathbf{1}} \mathbf{s}^{\mathbf{- 1}}\right)$} \\
\hline dns-GCxx sequence & $\mathbf{1 0} \boldsymbol{\mu} \mathbf{M} \mathbf{~ F P P}$ & $\mathbf{1 0} \boldsymbol{\mu} \mathbf{M}$ GGPP \\
dns-GCEV & $950 \pm 200$ & nd \\
dns-GCFT & $1900 \pm 70$ & $1700 \pm 300$ \\
dns-GCII & $1400 \pm 200$ & $700 \pm 100$ \\
dns-GCLL & $4000 \pm 100$ & $6100 \pm 1000$ \\
dns-GCNV & $1900 \pm 100$ & nd \\
dns-GCQL & $2500 \pm 90$ & nd \\
dns-GCRL & $340 \pm 100$ & nd \\
dns-GCSV & $1000 \pm 90$ & nd \\
dns-GCTV & $1900 \pm 40$ & nd \\
dns-GCVL & $2200 \pm 200$ & nd \\
dns-GCWI & $2600 \pm 200$ & nd \\
dns-GCYL & $1300 \pm 100$ & $920 \pm 30$ \\
dns-GCVLS & $170000 \pm 40000{ }^{c}$ & nd \\
\hline
\end{tabular}

${ }^{a}$ Steady-state analyses were carried out at saturating FPP or GGPP $(10 \mu \mathrm{M})$ and varying peptide concentrations $(0.5-10 \mu \mathrm{M})$ as described in Materials and Methods. Reported values are the average of at least three independent determinations, with the error indicating the standard deviation.

$b_{\text {No detectable activity. This assay has a lower limit for measuring } k_{\text {cat }} / K_{\mathrm{m}} 0.4 \mathrm{M}^{-1} \text { of s}}{ }^{-1}$ per ref 29.

$c_{\text {Previously reported per ref } 29 .}$ 